\title{
CELLS UNDER PRESSURE - THE RELATIONSHIP BETWEEN HYDROSTATIC PRESSURE AND MESENCHYMAL STEM CELL CHONDROGENESIS
}

\author{
G. Pattappa ${ }^{1, *}$, J. Zellner ${ }^{1}$, B. Johnstone ${ }^{2}$, D. Docheva ${ }^{1}$ and P. Angele ${ }^{1,3}$ \\ ${ }^{1}$ Laboratory of Experimental Trauma Surgery, Department of Trauma Surgery, \\ University Hospital Regensburg, Franz Josef Strauss Allee 11, 93053 Regensburg, Germany. \\ ${ }^{2}$ Department of Orthopaedics and Rehabilitation, Oregon Health and Science University, \\ 3181 SW Sam Jackson Park Rd, OP31, Portland, OR, USA. \\ ${ }^{3}$ Sporthopaedicum Regensburg, Hildegard von Bingen Strasse 1, 93053 Regensburg, Germany.
}

\begin{abstract}
Early osteoarthritis (OA), characterised by cartilage defects, is a degenerative disease that greatly affects the adult population. Cell-based tissue engineering methods are being explored as a solution for the treatment of these chondral defects. Chondrocytes are already in clinical use but other cell types with chondrogenic properties, such as mesenchymal stem cells (MSCs), are being researched. However, present methods for differentiating these cells into stable articular-cartilage chondrocytes that contribute to joint regeneration are not effective, despite extensive investigation. Environmental stimuli, such as mechanical forces, influence chondrogenic response and are beneficial with respect to matrix formation. In vivo, cartilage is subjected to multiaxial loading involving compressive, tensile, shear and fluid flow. The cellular response and tissue formation upon loading are being intensively studied in the cartilage tissue-engineering research field. The study of the effects of hydrostatic pressure on cartilage formation belongs to the large area of mechanobiology. During cartilage loading, interstitial fluid is pressurised and the surrounding matrix delays pressure loss by reducing fluid flow rate from pressurised regions. This fluid pressurisation is known as hydrostatic pressure, where a uniform stress around the cell occurs without cellular deformation. In vitro studies, examining chondrocytes under hydrostatic pressure, have described its anabolic effect and similar studies have evaluated the effect of hydrostatic pressure on MSC chondrogenesis. The present review summarises the results of these studies and discusses the mechanisms through which hydrostatic pressure exerts its effects.
\end{abstract}

Keywords: Cartilage, mesenchymal stem cells, chondrogenesis, hydrostatic pressure, mechanobiology, early osteoarthritis.

*Address for correspondence: Dr Girish Pattappa, Laboratory for Experimental Trauma Surgery, Department of Trauma Surgery, University Medical Centre Regensburg, Franz-Josef Strauss-Allee 11, Regensburg 93053, Germany.

Email: girish.pattappa@ukr.de

Copyright policy: This article is distributed in accordance with Creative Commons Attribution Licence (http://creativecommons.org/licenses/by-sa/4.0/).

\section{Introduction}

Articular cartilage lines the surface of synovial joints, providing a smooth and lubricated joint surface that facilitates load-bearing. The specialised cells that create and are located within this tissue are known as chondrocytes. The primary matrix components produced by these cells includes aggrecan (a large proteoglycan) and collagen II. Chondrocyte morphology and matrix distribution within the tissue creates an anisotropic structure (Fig. 1a,b). Anisotropy is seen not just from the cartilage surface to the subchondral bone (in the form of superficial, middle/transitional, deep and calcified zones) but also from the cell outward (pericellular, territorial and interterritorial regions) (Buckwalter et al., 2005; Sophia-Fox et al., 2009).

The superficial zone of the tissue contains a large proportion of collagen molecules interspersed with a low concentration of proteoglycans relative to the 
rest of the tissue. Chondrocytes are flattened and aligned parallel to the cartilage surface. Cells are larger and more spherical in the middle and deep zones of the cartilage. The thickness of collagen II fibrils increases with depth and orientation is altered to be perpendicular relative to those found in the upper layers. There is also an increase in aggrecan concentration with depth of the tissue (Fig. 1a; reviewed by Buckwalter et al., 2005; Sophia Fox et al., 2009). The high net negative charge of the glycosaminoglycan chains on these large proteoglycans attracts water and positive ions (e.g. potassium and sodium). However, the water concentration decreases towards the deep zone due to matrix restrictions, leading to an increased swelling pressure, enabling cartilage to withstand high compressive loads during joint loading (Maroudas and Bannon, 1981; Mow et al., 1984; Urban, 1994).

The anisotropy outwards from the chondrocyte is defined by a pericellular matrix, or chondron, which contains high concentrations of proteoglycans (e.g. perlecan and biglycan), other non-collagenous proteins and non-fibrillar collagens including collagen VI and IX. Collagen VI defines the boundary of the chondron. Surrounding this area is the territorial matrix, which is composed of larger collagen fibrils connected to both the pericellular matrix and the interterritorial matrix. The collagen in the territorial matrix is thought to protect the chondrocytes during mechanical loading. The interterritorial area incorporates the described cartilage zones and is the main contributor to cartilage biomechanics (Fig. 1b; Buckwalter et al., 2005; Mow et al., 1984; Sophia Fox et al., 2009).

Articular cartilage can undergo progressive degeneration due to a variety of aetiologies, resulting in osteoarthritis (OA). One of the early events in $\mathrm{OA}$ involves collagen fibrillation in the superficial layer that leads to loss of proteoglycans and increase in water content. Inflammatory cytokines stimulate the expression of matrix metalloproteinases (MMPs) and aggrecanases (ADAMTS) that degrade the tissue (Goldring, 2000; Goldring et al., 2011). Chondrocytes begin to proliferate, form clusters and induce matrix formation in response to tissue damage. Despite this initial repair phase, chondrocytes reduce their proliferative and anabolic response as the degeneration continues, leading to pain and changes in joint function, which are clinical indicators of OA (Buckwalter et al., 2005; Madry et al., 2012).

An increased risk of OA within the knee joint is associated with previous joint injury, excessive repetitive loading, joint dysplasia and meniscus removal. These described conditions result in abnormal cartilage loading and, thus, lead to degeneration. According to the Deutsche Gesellschaft für Orthopäedie und Unfallchirurgie (DGOU) registry, between October 2013 and June 2014, $60 \%$ of treated cartilage defects were degenerative, whilst a recent multi-centre study showed that from 400 patients, approximately $40 \%$ had chondral injuries resulting from degenerative conditions (Angele et al., 2015; Niemeyer et al., 2015). In classifying the forms of OA that can be treated, recent studies have used the term 'early OA' (Luyten et al., 2012; Madry et al., 2016; Madry et al., 2012). Focal early OA is focussed on the defect and the immediate surrounding environment. In clinical terms, the focal lesion [International Cartilage Regeneration \& Joint Preservation Society (ICRS) grade 3-4] is degenerative, whilst there is minimal degeneration (ICRS grade 1-2) in the surrounding cartilage area (defined by Madry et al., 2016). This condition may be treated using regenerative medicine or tissue engineering therapies. However, a high failure and re-operation rate is observed for focal degenerative defects as compared with those resulting from traumatic or chronic injury upon treatment using autologous chondrocyte implantation (ACI). A potential reason for their poor outcome is the surrounding inflammatory environment that impairs cell-based solutions. In particular, IL-1 $\beta$ has been shown to be a negative predictor for ACI treatment post-surgery (Angele et al., 2015; McNulty et al., 2013). Thus, a primary goal for clinicians and scientists is to develop regenerative options that can be used to treat both focal and diffuse early OA in this challenging environment.

Tissue engineering strategies may be useful for treating early osteoarthritic defects. The primary cell-based tissue engineering strategy for treating the described aetiology involves the use of autologous articular-cartilage chondrocytes (Brittberg et al., 1994). Alternative cell types such as mesenchymal stem cells (MSCs) from a variety of sources are being explored. These cells can be isolated from bone marrow, adipose tissue (liposuction or intrapatellar fat pad) or synovium with minimal donor site morbidity (Caplan, 1991; Gimble and Guilak, 2003; Pittenger et al., 1999; Sakaguchi et al., 2005). The use of pre-formed chondrogenic implants requires in vitro MSC chondrogenesis to be stimulated. Initially, this was performed through the creation of pellets or micromasses and addition of the stimulatory factor transforming growth factor beta 1 (TGF- $\beta 1$ ) (Johnstone et al., 1998; Yoo et al., 1998), which upregulates the transcription factors SOX9, SOX5 and SOX6 (Lefebvre et al., 2001; Lefebvre et al., 1997). The expression of these transcription factors, and specifically SOX9, leads to collagen II and aggrecan expression and synthesis (Fig. 1c). Since the development of this method for the chondrogenic differentiation of stem/progenitor cells, the field has expanded to include cellular chondrogenesis within scaffolds/biomaterials to create tissue constructs of a clinically relevant size for filling cartilage defects within patient's joints. Unfortunately, these cell-biomaterial constructs usually have inferior biochemical and mechanical properties when compared with the native tissue (Erickson et al., 2009). Moreover, in both pellets and scaffolds, markers of chondrocyte hypertrophy (collagen type X, MMP- 
13) have been detected and, upon implantation in vivo, ectopic bone formation can occur (Pelttari et al., 2006). Strategies to prevent hypertrophy and produce a stable chondrocyte phenotype with its defined extracellular matrix are the goal of in vitro cartilage tissue engineering.

Scientists have attempted to attain stable cartilage formation with environmental stimuli relevant to the in vivo situation, e.g. biomechanical stimulation, lower oxygen tension and/or addition of growth factors. Chondrocytes and MSC have been shown to respond to mechanical loading and alter their matrix production in response to different stimuli (reviewed by Anderson and Johnstone, 2017; Huang et al., 2010a; O'Conor et al., 2013). One of the simplest stimuli that is involved in cartilage biomechanics is hydrostatic pressure. This involves fluid pressurisation and has been shown to increase tissue formation upon application to articular cartilage chondrocytes (reviewed by Elder and Athanasiou, 2009; Salinas et al., 2018). The present review summarises the literature and evaluates the effects of hydrostatic pressure on MSC chondrogenesis, summarising the outcomes of the various studies and the pathways that have been identified to be part of the cellular response to it.

\section{Generation of hydrostatic pressure in articular cartilage}

Hydrostatic pressure is the application of a uniform stress without cellular deformation. In vivo, this is generated by pressurisation of interstitial water within articular cartilage. Theoretical models (e.g. biphasic theory) predicting articular cartilage mechanics show that upon loading, cartilage develops a resistance to fluid flow and generates a pressure within the matrix: the hydrostatic pressure. These models predict that approximately $90 \%$ of load is initially borne by fluid pressurisation between cartilage layers, which contributes to its viscoelastic properties (Bachrach et al., 1998; Carter and Wong, 2003; Soltz and Ateshian, 1998; Soltz and Ateshian, 2000). Soltz and Ateshian $(1998,2000)$ demonstrated the generation of pressure within articular cartilage in an experimental setting. They found that the interstitial fluid or water within the matrix is subjected to hydrostatic pressure, whilst the collagen-proteoglycan matrix helps delay pressure loss through retarding the rate of fluid flow away from pressurised regions. It may be postulated that the highest hydrostatic pressure occurs below the superficial layer due to the presence of proteoglycans attracting water within these layers during compression (Fig. 1a). This form of loading causes no cellular or tissue deformation and has been hypothesised to play a role in protecting chondrocytes and articular cartilage matrix from excessive loads generated within the joint (Soltz and Ateshian, 1998). Measurements of hydrostatic pressure during loading suggest that the peak pressure can be up to $12 \mathrm{MPa}$ (Soltz and Ateshian, 2000). In contrast, compression and shear loading, also contributory to cartilage biomechanics, involve both cellular and tissue deformation. Thus, hydrostatic pressure applies its mechanical load in a distinct manner.

Pressure directs chondrogenic fate during joint development (Carter and Wong, 2003; Giorgi et al., 2014). Giorgi et al. (2014) found in a computational model that dynamic/cyclic hydrostatic pressure promotes cartilage formation, whereas static pressure induces bone formation during prenatal joint morphogenesis. Theoretical models have also suggested that pressure helps to maintain the chondrocyte phenotype within the cartilage (Carter and Wong, 2003). Thus, according to these models, hydrostatic pressure drives chondrogenesis during the embryonic and mesenchymal phase, whilst helping to maintain chondrocyte phenotype at maturity. A previous review addressed the effects of hydrostatic pressure on chondrocytes (Elder and Athanasiou, 2009). In summary, chondrocytes subjected to hydrostatic pressure demonstrate an enhanced chondrocyte matrix production, particularly between 0.1 and $10 \mathrm{MPa}$ under either static or cyclic settings, as compared with unloaded controls. Recent investigations have also begun to examine the effects of hydrostatic pressure on MSCs from a variety of animal and tissue sources (Table 1-3).

\section{Hydrostatic pressure and MSC chondrogenesis}

The first study to investigate the effect of hydrostatic pressure on MSCs was performed by Angele et al. (2003) (Table 1a,b). Pressure was applied to MSC pellets during the first week of culture using a loading regime within a physiological range (0.55$5 \mathrm{MPa}$ at $1 \mathrm{~Hz} ; 4 \mathrm{~h} / \mathrm{d}$ ). The results demonstrated that there is an increase in glycosaminoglycans (GAG) and collagen matrix synthesis after loading at day 14 and 28, whilst pellets loaded only on day 1 and 3 do not increase matrix deposition with respect to the unloaded control (Angele et al., 2003). Following this study, similar studies used continuous hydrostatic pressure $(0.5-5 \mathrm{MPa}, 0.5 \mathrm{~Hz})$ applied to adipose-derived MSCs seeded within a collagen type I scaffold with medium replenishment during the loading phase. These latter studies showed that SOX9, collagen type II alpha 1 chain (COL2A1) and aggrecan $(A C A N)$ are upregulated at weeks 2 and 4, whilst the early hypertrophy marker, COL10A1, is upregulated in the loaded groups from weeks 3 onwards (Ogawa et al., 2009). Other investigations obtained similar results, whereby chondrogenic (SOX9, COL1A1, COL2A1 and ACAN) and matrix synthesis (GAG and $C O L)$ gene are increased upon application of hydrostatic pressure following either 14 or $21 \mathrm{~d}$ of application (Carroll et al., 2014; Correia et al., 2012; Elder et al., 2008; Miyanishi et al., 2006; Ogawa et al., 2009; Ogawa et al., 2015; Saha et al., 2017; Sakao et al., 2008; Steward et al., 2014; Steward 
a

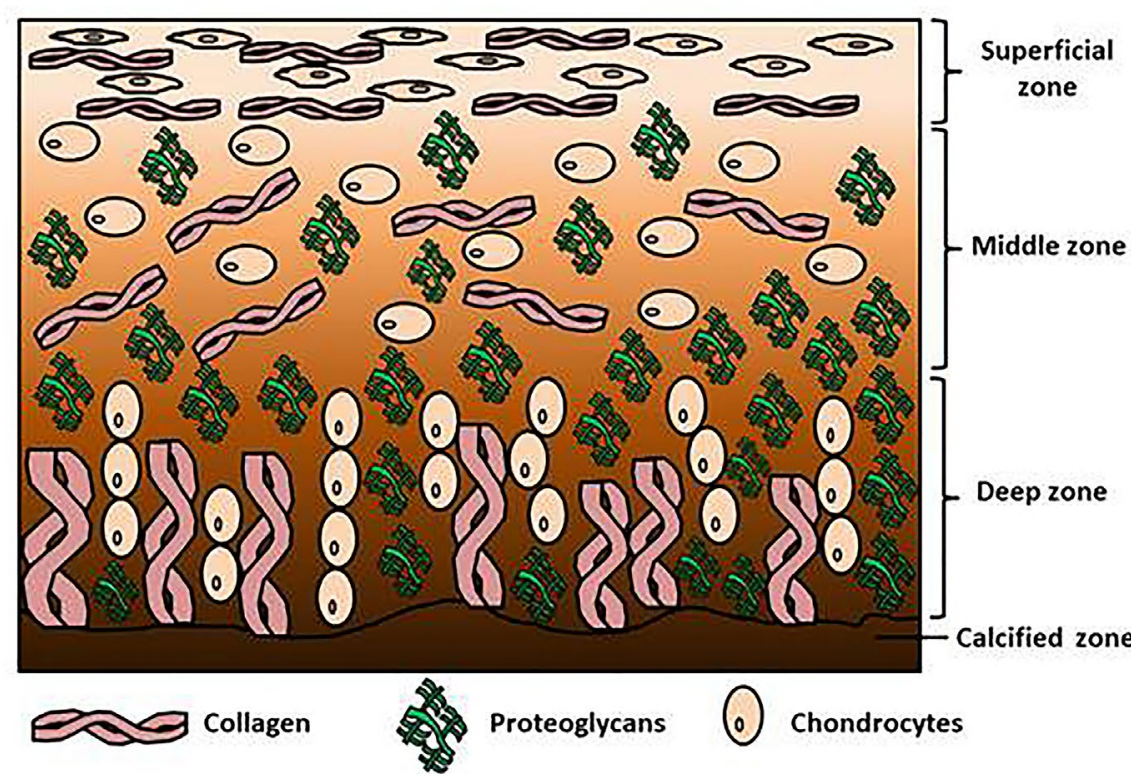

$0.1 \mathrm{MPa}$

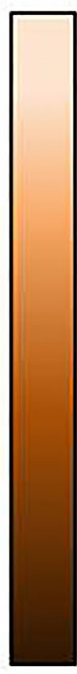

Hydrostatic

pressure

gradient

b

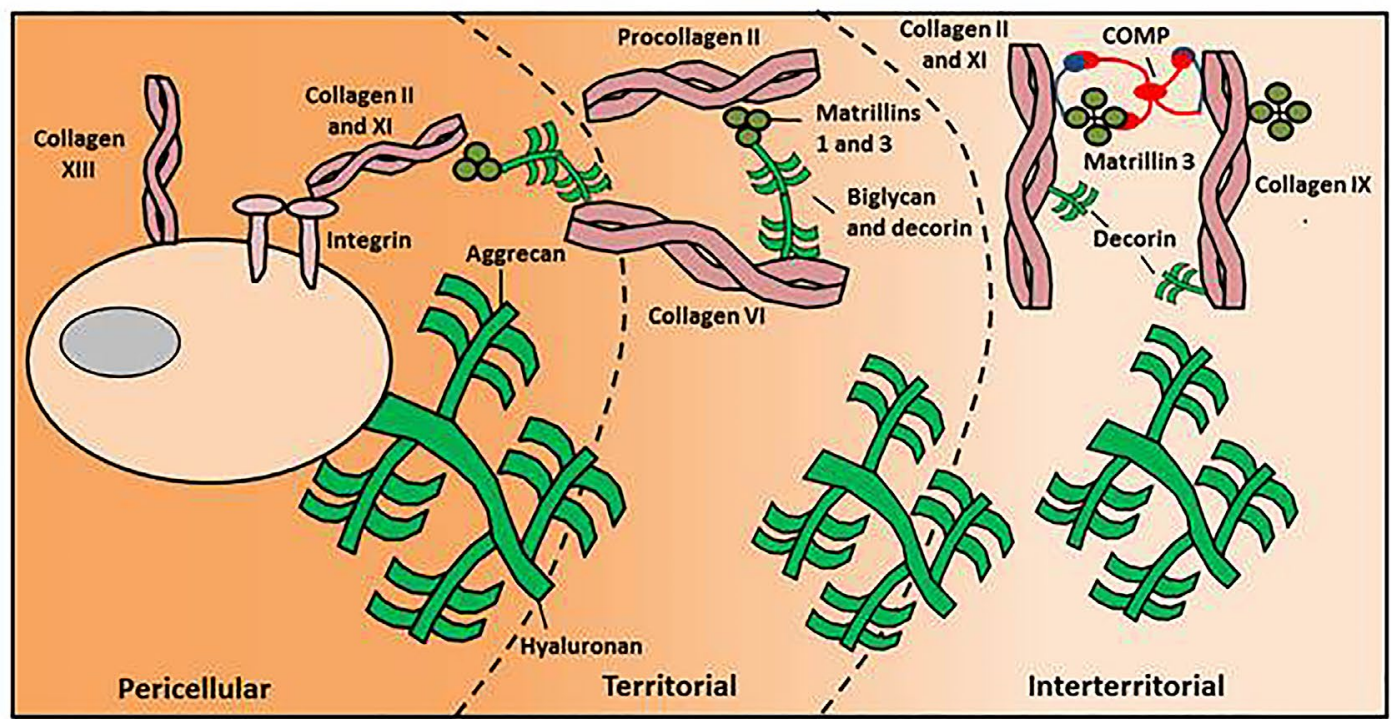

C

MSCs

Chondroprogenitors

Chondroblasts

Chondrocytes

Hypertrophic Chondrocytes

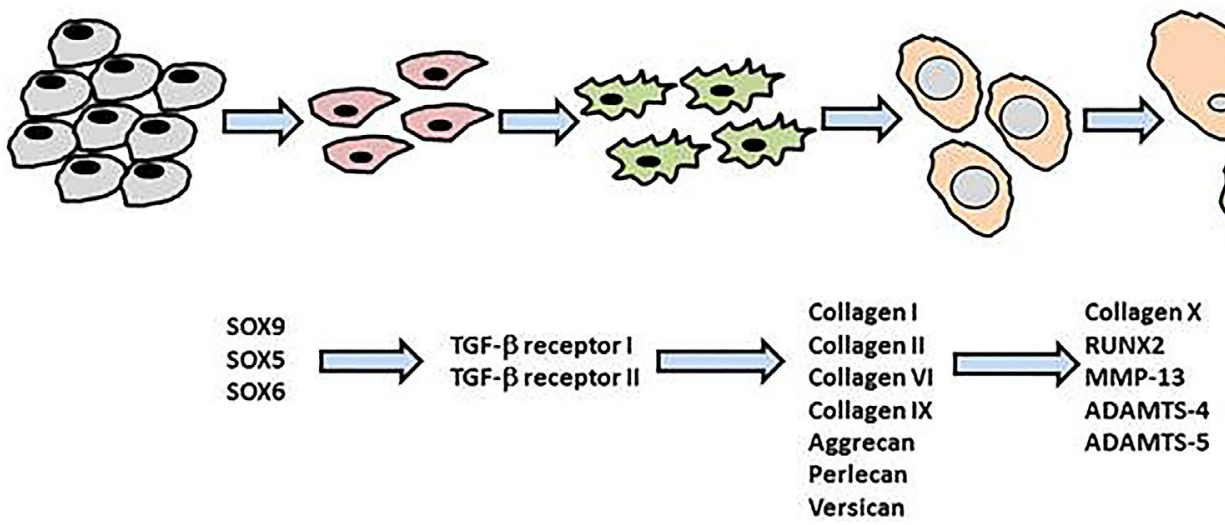

Fig. 1. Schematic diagram. (a) Zones of articular cartilage depicting the arrangement and orientation of chondrocytes, collagens and proteoglycans within the extracellular matrix and the changes in hydrostatic pressure. (b) A simplified diagram of the matrix regions surrounding the chondrocyte, specifically the pericellular, territorial ad interterritorial matrix and the specific matrix molecule arrangements within these regions. (c) The processes involved in MSC chondrogenesis with respect to chondrocyte maturation and the genes involved at each stage of the process. 
et al., 2016; Steward et al., 2012; Steward et al., 2013; Wagner et al., 2008; Ye et al., 2014; Zhao et al., 2015) (Table 1-3). Loading magnitude and duration, length of chondrogenic pre-culture or preconditioning prior to pressure application and inclusion/exclusion of TGF- $\beta$ influence the chondrogenic response of MSCs.

Loading magnitude and duration of pressure on MSC chondrogenesis

Loading magnitudes ranging from 0.1-10 $\mathrm{MPa}$ enhance MSC chondrogenesis (Angele et al., 2003; Correia et al., 2012; Karkhaneh et al., 2014; Miyanishi et al., 2006; Ogawa et al., 2009; Vinardell et al., 2012). Miyanishi et al. (2006b) showed that there is a loaddependent matrix gene expression and deposition, whereby 0.1-1 MPa loading can increase SOX9, $C O L 2 A 1$ and $A C A N$ expression, although peak expression for the latter two genes occurs at $10 \mathrm{MPa}$. The latter magnitude induces a significant increase in GAG and collagen matrix formation, indicating that different magnitudes elicit differential responses in MSCs at the gene and protein level (Table 1a,b).

Correia et al. (2012), under similar conditions and using adipose MSCs $(4 \mathrm{~h} / \mathrm{d}$ at $0.5 \mathrm{~Hz})$, reproduced these results: high peak magnitudes (7.5 MPa) increase matrix deposition from adipose MSCs, whilst low magnitudes (0.4 MPa) upregulate COL2A1. However, other investigations have also shown that 0.5-1 MPa hydrostatic pressure is sufficient to enhance MSC chondrogenesis, although no comparisons are made with other peak pressures (Ogawa et al., 2009; Saha et al., 2017; Wagner et al., 2008). In summary, although loading magnitude results in differing gene expression profiles and matrix production response, pressure generally induces an anabolic effect on MSC chondrogenesis.

There has not been extensive research on the effects of pressure duration on chondrogenic MSCs. The loading duration in these and most of the studies investigating hydrostatic pressure on MSC chondrogenesis is $4 \mathrm{~h} / \mathrm{d}$. Based on the current literature, it can be stated that pressure can enhance chondrogenesis when applied between 1-4 h/d but there is no information on the optimal loading period (Elder et al., 2008; Karkhaneh et al., 2014; Luo and Seedhom, 2007; Meyer et al., 2011; Sakao et al., 2008; Ye et al., 2014; Zhao et al., 2016; Zhao et al., 2015).

\section{TGF- $\beta$ presence and endogenous production in pressure-stimulated MSC chondrogenesis}

Most studies of pressure-induced chondrogenesis used MSCs cultured in the presence of $10 \mathrm{ng} / \mathrm{mL}$ TGF- $\beta$. Enhanced chondrogenesis as compared with unloaded controls is documented with $1 \mathrm{ng} /$ mL TGF- $\beta$ using either bone-marrow-, synoviumor adipose-derived MSCs (Miyanishi et al., 2006; Vinardell et al., 2012). However, larger increases in gene expression and matrix formation are observed at $10 \mathrm{ng} / \mathrm{mL} \mathrm{TGF}-\beta$ with hydrostatic pressure applied.
Miyanishi et al. (2006a) examined the application of hydrostatic pressure without TGF- $\beta$ on bone marrow MSCs. At $10 \mathrm{MPa}, 1 \mathrm{~Hz}$ for $4 \mathrm{~h} / \mathrm{d}$, they detected significant increases in SOX9, COL2A1 and ACAN expression and matrix deposition (aggrecan and collagen II staining) following $14 \mathrm{~d}$ of loading. Finger et al. (2007) examined this phenomenon and found that SOX9 is upregulated in MSCs upon loading at $7.5 \mathrm{MPa}$ hydrostatic pressure. However, a follow-up study showed that despite an upregulation in both SOX9 and ACAN expression during the first week, there is no chondrogenic gene expression at later time points due to loss of cell viability (Puetzer et al., 2013). In agreement with these results, Safeshaken et al. (2012), using a pellet culture model, demonstrated no increase in chondroinduction without TGF- $\beta$ addition using a loading regime (0-5 $\mathrm{MPa}$ at $0.5 \mathrm{~Hz}$ for $4 \mathrm{~h} / \mathrm{d}$ ) for $10 \mathrm{~d}$ only. Thus, whether hydrostatic pressure alone is sufficient to induce chondrogenesis to any significant degree remains unresolved (Carroll et al., 2014; Finger et al., 2007; Li et al., 2012; Li et al., 2009; Puetzer et al., 2013; Vinardell et al., 2012; Ye et al., 2014) (Table 2).

Specially designed multiaxial mechanical loading systems that simulate knee biomechanics and involve compression, shear and hydrostatic pressure stimulate endogenous TGF- $\beta$ (Gardner et al., 2016b; Li et al., 2010; Safshekan et al., 2012; Schatti et al., 2011). Importantly, the application of mechanical forces, and more specifically shear loading, induces conversion of TGF- $\beta$ from its latent to active form (Ahamed et al., 2008; Albro et al., 2012; Gardner et al., 2016b). Hydrostatic pressure alone stimulates active TGF- $\beta$ secretion from chondrogenic MSC without TGF- $\beta$ supplementation (Li et al., 2012; Maxson and Burg, 2012; Ye et al., 2014). However, it should be noted that cells subjected to hydrostatic pressure are either stimulated with TGF- $\beta$ prior to loading (Li et al., 2012; Ye et al., 2014) or cultured in conditioned medium containing TGF- $\beta$ under pressure (Maxson and Burg, 2012). This contrasts with the described multiaxial loading studies, in which MSCs undergo chondrogenesis in the absence of TGF- $\beta$ during loading (Gardner et al., 2016b; Li et al., 2010; Schatti et al., 2011). Contrary to previous hydrostatic pressure publications, Vinardell et al. (2012) demonstrated that without TGF- $\beta$ pre-stimulation from the outset, pressure alone do not induce endogenous TGF- $\beta$ production from MSCs. Thus, based on these studies, TGF- $\beta$ pre-differentiation may be required for pressure alone to induce endogenous production, although the mechanism needs to be fully understood.

\section{Chondrogenic MSC pre-differentiation and response under hydrostatic pressure}

Loading of chondrogenic pre-cultured MSCs at different stages of differentiation has been examined in mechanical loading systems involving 
Table 1a. Summary of the effects of hydrostatic pressure on MSC chondrogenesis under different loading regimes.

\begin{tabular}{|c|c|c|c|c|}
\hline Publication & Cell source & Pellet/scaffold & Loading regime & Principal findings \\
\hline $\begin{array}{l}\text { Angele et al., } \\
2003\end{array}$ & $\begin{array}{l}\text { Human bone } \\
\text { marrow MSCs }\end{array}$ & Pellet & $\begin{array}{c}\text { Cyclic, } \\
0.555 \mathrm{MPa}, 1 \mathrm{~Hz} \\
4 \mathrm{~h} / \mathrm{d}, \text { loading on } \\
\text { day } 1,3 \text { or } 17\end{array}$ & $\begin{array}{l}\text { Pellet size, GAG and collagen synthesis } \\
\text { significantly increase from day } 17 \text { after } \\
\text { loading application as compared to unloaded } \\
\text { control. } \\
\text { No effect of loading on single loading days. }\end{array}$ \\
\hline $\begin{array}{l}\text { Miyanishi et al., } \\
\text { 2006b }\end{array}$ & $\begin{array}{l}\text { Human bone } \\
\text { marrow MSCs }\end{array}$ & Pellet & $\begin{array}{l}\text { Cyclic, } 0.1,1 \\
10 \mathrm{MPa} \text { at } 1 \mathrm{~Hz} \\
4 \mathrm{~h} / \mathrm{d}, 14 \mathrm{~d} \\
\text { continuously }\end{array}$ & $\begin{array}{l}\text { Increased SOX9 and } A C A N \text { expression } \\
\text { peaking at } 10 \mathrm{MPa} \text {. } \\
\text { GAG synthesis upregulated at } 1 \text { and } 10 \mathrm{MPa} \text {, } \\
\text { whilst collagen synthesis increases only at } \\
10 \mathrm{MPa} \text {. }\end{array}$ \\
\hline Elder et al., 2008 & $\begin{array}{c}\text { Murine } \\
\text { embryonic cell } \\
\text { line }(\mathrm{CH} 310 \mathrm{~T} 1 / 2) \\
\end{array}$ & Pellet & $\begin{array}{l}\text { Cyclic, } 0.55 \mathrm{MPa}, \\
1 \mathrm{~Hz}, 3 \mathrm{~h} / \mathrm{d}, 3 \mathrm{~d}\end{array}$ & $\begin{array}{c}\text { Enhanced SOX9 and } A C A N \text { expression upon } \\
\text { loading. }\end{array}$ \\
\hline Sakao et al., 2008 & $\begin{array}{l}\text { Rabbit synovium } \\
\text { MSCs }\end{array}$ & $\begin{array}{c}\text { Scaffold } \\
\left(4 \times 10^{6} \text { cells/ }\right. \\
\text { mL in } 1.2 \% \\
\text { alginate beads - } \\
\text { synovium MSCs })\end{array}$ & $\begin{array}{c}\text { Cyclic, } 15 \mathrm{MPa}, \\
0.5 \mathrm{~Hz}, 1 \mathrm{~h} / \mathrm{d}\end{array}$ & $\begin{array}{l}\text { SOX9 and COL2 expression and GAG } \\
\text { synthesis upregulated upon loading. }\end{array}$ \\
\hline $\begin{array}{l}\text { Wagner et al., } \\
2008\end{array}$ & $\begin{array}{l}\text { Human bone } \\
\text { marrow MSCs }\end{array}$ & $\begin{array}{c}\text { Scaffold } \\
\left(1 \times 10^{6} \text { cells } / \mathrm{mL} ;\right. \\
\text { collagen type I } \\
\text { construct })\end{array}$ & $\begin{array}{l}\text { Cyclic, } 1 \mathrm{MPa}, \\
1 \mathrm{~Hz}, 4 \mathrm{~h} / \mathrm{d} \text { for } \\
10 \mathrm{~d}\end{array}$ & $\begin{array}{c}\text { Upregulated SOX9, ACAN, COL1A1 and } \\
\text { COL2A1 expression. } \\
\text { More GAG matrix staining in loaded } \\
\text { constructs. }\end{array}$ \\
\hline $\begin{array}{l}\text { Ogawa et al., } \\
2009\end{array}$ & $\begin{array}{l}\text { Human adipose } \\
\text { MSCs }\end{array}$ & $\begin{array}{c}\text { Scaffold } \\
\left(1 \times 10^{6} \text { cells } / \mathrm{mL} ;\right. \\
\text { collagen type I } \\
\text { construct })\end{array}$ & $\begin{array}{c}\text { Cyclic, } 0.5 \mathrm{MPa}, \\
0.5 \mathrm{~Hz} \text {, week } \\
1 \text { loaded } \\
\text { (continuously/no } \\
\text { rest under load) } \\
\end{array}$ & $\begin{array}{c}\text { SOX9, ACAN, COL } 2 A 1 \text { and COLX expression } \\
\text { increase under loading } \\
\text { More collagen II and keratin sulphate } \\
\text { staining after loading. }\end{array}$ \\
\hline $\begin{array}{l}\text { Correia et al., } \\
\quad 2012\end{array}$ & $\begin{array}{l}\text { Human adipose } \\
\text { MSCs }\end{array}$ & $\begin{array}{l}\text { Scaffold } \\
\left(10 \times 10^{6} \text { cells/ }\right. \\
\text { mL; collagen } \\
\text { type I construct })\end{array}$ & $\begin{array}{c}\text { Cyclic; high: } \\
5 \mathrm{MPa}, 0.5 \mathrm{~Hz}, \\
4 \mathrm{~h} / \mathrm{d}, 5 \mathrm{~d} / \text { week; } \\
\text { low: } 0.4 \mathrm{MPa}, \\
0.5 \mathrm{~Hz}, 4 \mathrm{~h} / \mathrm{d} \\
5 \mathrm{~d} / \text { week } \\
\end{array}$ & $\begin{array}{c}\text { No difference in } S O X 9 \text { expression under } \\
\text { either loading regime; } A C A N \text { expression } \\
\text { peaks at } 5 \mathrm{MPa} \text {, whilst } C O L 2 A 1 \text { at } 0.4 \mathrm{MPa} \text {. } \\
\text { More GAG accumulation and matrix staining } \\
\text { under high hydrostatic loading. }\end{array}$ \\
\hline $\begin{array}{l}\text { Steward et al., } \\
2012\end{array}$ & $\begin{array}{l}\text { Porcine bone } \\
\text { marrow MSCs }\end{array}$ & $\begin{array}{c}\text { Scaffold } \\
\left(15 \times 10^{6} \text { cells } /\right. \\
\text { mL; } 2 \% \text { agarose } \\
\text { or fibrin })\end{array}$ & $\begin{array}{c}\text { Cyclic, } 10 \mathrm{MPa} \text {, } \\
1 \mathrm{~Hz}, 4 \mathrm{~h} / \mathrm{d}, 5 \mathrm{~d} / \\
\text { week for } 5 \text { weeks } \\
1 \mathrm{ng} / \mathrm{mL} \text { or } \\
10 \mathrm{ng} / \mathrm{mL} \mathrm{TGF}-\beta\end{array}$ & $\begin{array}{l}\text { GAG synthesis increases and collagen I } \\
\text { decreases in fibrin hydrogels upon loading, } \\
\text { whilst more pericellular matrix is observed in } \\
\text { agarose gels. } \\
\text { ALP activity suppressed upon loading in the } \\
\text { presence of } 10 \mathrm{ng} / \mathrm{mL} \text { TGF- } \beta \text { in agarose gels. }\end{array}$ \\
\hline $\begin{array}{l}\text { Steward et al., } \\
2013\end{array}$ & $\begin{array}{l}\text { Porcine bone } \\
\text { marrow MSCs }\end{array}$ & $\begin{array}{l}\text { Scaffold } \\
{\left[15 \times 10^{6} \text { cells in }\right.} \\
1 \%, 2 \% \text { or } 4 \% \\
(\mathrm{w} / \mathrm{v}) \text { agarose }]\end{array}$ & $\begin{array}{l}\text { Cyclic, } 10 \mathrm{MPa} \text {, } \\
1 \mathrm{~Hz}, 4 \mathrm{~h} / \mathrm{d} \\
5 \mathrm{~d} / \text { week }\end{array}$ & $\begin{array}{c}\text { SOX9, COL2A1 and ACAN expression } \\
\text { increases upon loading within stiffer } \\
\text { hydrogels. } \\
\text { Application of integrin inhibitor (RGDS) } \\
\text { reduces chondrogenic response under } \\
\text { loading. }\end{array}$ \\
\hline $\begin{array}{l}\text { Carroll et al., } \\
\quad 2014\end{array}$ & $\begin{array}{c}\text { Human bone } \\
\text { marrow MSCs } \\
\text { and infrapatellar } \\
\text { fat pad MSCs }\end{array}$ & $\begin{array}{c}\text { Scaffold } \\
\left(20 \times 10^{6} \text { cells } /\right. \\
\mathrm{mL} ; 2 \% \text { agarose })\end{array}$ & $\begin{array}{c}\text { Cyclic, } 10 \mathrm{MPa} \text {, } \\
1 \mathrm{~Hz}, 4 \mathrm{~h} / \mathrm{d}, 5 \mathrm{~d} / \\
\text { week for } 5 \text { weeks }\end{array}$ & $\begin{array}{c}\text { Pressure increases GAG and collagen } \\
\text { synthesis in both cell types. More collagen II } \\
\text { staining in bone marrow MSCs. } \\
\text { Reduced alizarin red staining under } \\
\text { pressure; potentially preventing hypertrophy } \\
\text { dynamic and equilibrium modulus increases } \\
\text { upon loading application. }\end{array}$ \\
\hline
\end{tabular}

compression and/or in combination with shear (reviewed by O'Conor et al., 2013). These studies show that the longer the pre-differentiation period prior to loading the larger the increase in cartilage gene expression and matrix production upon stimulation. Continuous loading at the start of culture appears to be detrimental, indicating that a period of pre-culturing or pre-differentiation prior to loading is beneficial for MSC chondrogenesis
(Huang et al., 2010b; Thorpe et al., 2010). This indicates the importance of early matrix formation, especially pericellular matrix, to enable transmission of the compressive force (mechanotransduction), mimicking that produced in in vivo cartilage.

Similar results have been found varying the point of hydrostatic loading on differentiating chondrogenic MSCs (Li et al., 2012; Li et al., 2016; Luo and Seedhom, 2007; Ogawa et al., 2015; Safshekan 
Table 1b. Summary of the effects of hydrostatic pressure on MSC chondrogenesis under different loading regimes.

\begin{tabular}{|c|c|c|c|c|}
\hline Publication & Cell source & Pellet/scaffold & Loading regime & Principal findings \\
\hline $\begin{array}{l}\text { Steward et al., } \\
2014\end{array}$ & $\begin{array}{l}\text { Porcine bone } \\
\text { marrow MSCs }\end{array}$ & $\begin{array}{c}\text { Scaffold } \\
\left(15 \times 10^{6} \text { cells } /\right. \\
\mathrm{mL} ; 4 \% \text { agarose })\end{array}$ & $\begin{array}{l}\text { Cyclic, } 10 \mathrm{MPa} \text {, } \\
1 \mathrm{~Hz}, 4 \mathrm{~h} / \mathrm{d} \\
5 \mathrm{~d} / \text { week }\end{array}$ & $\begin{array}{l}\text { Pressure enhances GAG and collagen II } \\
\text { matrix deposition. } \\
\text { Calcium signalling inhibition prevents } \\
\text { anabolic response but stretch-activated } \\
\text { channels inhibition does not affect response. }\end{array}$ \\
\hline Ye et al., 2014 & $\begin{array}{c}\text { Rat bone marrow } \\
\text { MSCs }\end{array}$ & $\begin{array}{l}\text { Pellets } \\
\text { 17 } \beta \text {-oestradiol } \\
\left(\mathrm{E}_{2}\right) ; \text { tamoxifen } \\
\text {-ER } \alpha \text { blocker }\end{array}$ & $\begin{array}{c}\text { Cyclic, } 90 \mathrm{kPa} \text { for } \\
1 \mathrm{~h} / \mathrm{d}\end{array}$ & $\begin{array}{c}\text { SOX9, ACAN and COL2A1 expression } \\
\text { upregulated and GAG synthesis increased } \\
\text { under loading. } \\
\text { 17ß-oestradiol and loading enhance response } \\
\text { via JNK phosphorylation and expression, } \\
\text { whilst presence of tamoxifen prevents load- } \\
\text { induced chondrogenic response. }\end{array}$ \\
\hline $\begin{array}{c}\text { Ogawa et al., } \\
2015\end{array}$ & $\begin{array}{l}\text { Human adipose } \\
\text { MSCs }\end{array}$ & $\begin{array}{l}\text { Scaffold } \\
\left(1 \times 10^{6} \text { cells } / \mathrm{mL} ;\right. \\
\text { collagen type I } \\
\text { construct })\end{array}$ & $\begin{array}{l}\text { Cyclic, } 0.5 \mathrm{MPa} \text {, } \\
0.5 \mathrm{~Hz} \text {, week } 1 \\
\text { loaded, week } 1 \\
\text { and } 3 \text { loaded, } \\
\text { continuous } \\
\text { loading }\end{array}$ & $\begin{array}{l}\text { Week } 1 \text { loading is sufficient to induce } \\
\text { chondrogenesis. } \\
\text { SOX9, ACAN,COL2A1,COLXA1 and MMP3 } \\
\text { and MMP13 upregulated upon loading - } \\
\text { more GAG and collagen matrix synthesis. }\end{array}$ \\
\hline Zhao et al., 2015 & $\begin{array}{c}\text { Rat bone marrow } \\
\text { MSCs }\end{array}$ & Pellet & $\begin{array}{c}90 \mathrm{kPa} \text { cyclic, } \\
1 \mathrm{~h}, 4 \text { weeks } \\
\text { continuous } \\
\text { loading } \\
\end{array}$ & $\begin{array}{l}\text { SOX9, ACAN and COL2A1 expression and } \\
\text { GAG synthesis upregulated with Rac1 } \\
\text { agonist and RhoA antagonist under loading. }\end{array}$ \\
\hline $\begin{array}{l}\text { Steward et al., } \\
2016\end{array}$ & $\begin{array}{l}\text { Porcine bone } \\
\text { marrow MSCs }\end{array}$ & $\begin{array}{c}\text { Scaffold } \\
{\left[15 \times 10^{6} \text { cells in }\right.} \\
1 \% \text { or } 4 \%(w / v) \\
\text { agarose }]\end{array}$ & $\begin{array}{l}\text { Cyclic, } 10 \mathrm{MPa} \text {, } \\
1 \mathrm{~Hz}, 4 \mathrm{~h} / \mathrm{d} \\
5 \mathrm{~d} / \text { week }\end{array}$ & $\begin{array}{l}\text { Pressure increases extracellular ATP } \\
\text { production through hemichannels and } \\
\text { facilitates anabolism under loading. } \\
\text { Inhibition of hemichannels, P-receptors or } \\
\text { extracellular ATP, suppressed chondrogenic } \\
\text { response - vimentin structure unaltered in } \\
\text { the presence of inhibitors. }\end{array}$ \\
\hline Saha et al., 2017 & $\begin{array}{l}\text { Murine } \\
\text { embryonic limb } \\
\text { bud cells }\end{array}$ & $\begin{array}{c}\text { Scaffold } \\
\left(2 \times 10^{7} \text { cells } / \mathrm{mL} ;\right. \\
1.8 \% \text { agarose })\end{array}$ & $\begin{array}{l}\text { Cyclic, } 1 \mathrm{MPa}, \\
1 \mathrm{~Hz}, 4 \mathrm{~h} / \mathrm{d}, 8 \mathrm{~d} \\
\quad \text { loading }\end{array}$ & $\begin{array}{c}\text { SOX9 expression increases under loading. } \\
\text { COLXA1 and } I H H \text { expression decreases } \\
\text { under loading - collagen } X \text { staining also } \\
\text { reduced. }\end{array}$ \\
\hline
\end{tabular}

et al., 2012; Ye et al., 2014). In general, application of pressure after a period of pre-differentiation (7 or $21 \mathrm{~d}$ ) enhances chondrogenesis as compared with unloaded controls (Table 3a,b). Meyer et al. (2011), using a cell-agarose model, studied whether hydrostatic pressure, used either at the onset or delayed ( $21 \mathrm{~d})$, resulted in enhanced chondrogenesis. In contrast to compressive and shear loading studies, application of hydrostatic pressure at the onset produces more matrix formation (GAG, collagens I, II) and increased mechanical properties (Young's and dynamic modulus) as compared to pre-differentiated MSCs. Despite no in-depth studies regarding the effect of different periods of pre-differentiation, it may be hypothesised that hydrostatic pressure has a larger effect on MSC chondrogenesis during its early stages as suggested in computational/theoretical models, whilst compressive loading exerts its influence on pre-differentiated MSCs, specifically at later stages of chondrogenesis.

Hypertrophic MSC chondrogenesis and hydrostatic pressure

Some investigations examining pressure-stimulated chondrogenesis found that the hypertrophic markers COL10A1, MMP-13 and Indian hedgehog $(I H H)$ are upregulated (Li et al., 2012; Ogawa et al., 2009; Ogawa et al., 2015). However, other investigations have detected downregulation in gene expression of these markers (Liu et al., 2014; Saha et al., 2017; Steward et al., 2012; Vinardell et al., 2012). Furthermore, when Carroll et al. (2013) stimulated encapsulated MSCs in normal chondrogenic medium for 3 weeks and, then, in hypertrophic medium for 2 weeks, hydrostatic pressure helped to suppress MSC calcification during culture in hypertrophic medium, whilst increasing collagen and glycosaminoglycan content. Saha et al. (2017), using murine embryonic limb bud cells subjected to hydrostatic loading, had similar results and showed reduced collagen $X$ protein deposition. Given the conflicting results, the effects of hydrostatic pressure on chondrocyte hypertrophy need further study for conclusive statements to be made about its effects.

\section{Signalling pathways under the influence of hydrostatic pressure}

Hydrostatic pressure demonstrates a prochondrogenic effect, whereby matrix synthesis is enhanced upon stimulation. The pathways that 
Table 2. Summary of publications examining the influence of TGF- $\beta$ on pressure-induced chondrogenesis.

\begin{tabular}{|c|c|c|c|c|c|}
\hline Publication & Cell source & Pellets/scaffold & $\begin{array}{l}\text { Loading } \\
\text { regime }\end{array}$ & $\begin{array}{c}\text { TGF- } \beta \\
\text { conditions }\end{array}$ & Principal findings \\
\hline $\begin{array}{c}\text { Miyanishi et al., } \\
\text { 2006a }\end{array}$ & $\begin{array}{l}\text { Human bone } \\
\text { marrow MSCs }\end{array}$ & Pellet & $\begin{array}{l}\text { Cyclic, } 1 \mathrm{~Hz}, \\
10 \mathrm{MPa} \\
4 \mathrm{~h} / \mathrm{d}, 14 \mathrm{~d} \\
\text { continuously }\end{array}$ & $\begin{array}{c}0 \mathrm{ng} / \mathrm{mL} \\
10 \mathrm{ng} / \mathrm{mL}\end{array}$ & $\begin{array}{c}\text { SOX9, COL2A1 and ACAN increased } \\
\text { expression under pressure with or } \\
\text { without TGF- } \beta \text {. } \\
\text { More matrix synthesis in the } \\
\text { presence of both TGF- } \beta \text { and } \\
\text { pressure. }\end{array}$ \\
\hline $\begin{array}{c}\text { Finger et al., } \\
2007\end{array}$ & $\begin{array}{c}\text { Bone marrow } \\
\text { MSCs }\end{array}$ & $\begin{array}{l}\text { Scaffold } \\
\left(9 \times 10^{6} \text { cells/ }\right. \\
\mathrm{mL} ; 2 \% \\
\text { agarose })\end{array}$ & $\begin{array}{c}\text { Steady cyclic } \\
\text { loading, } \\
7.5 \mathrm{MPa}, 1 \mathrm{~Hz}, \\
4 \mathrm{~h} / \mathrm{d}(14 \mathrm{~d}) \text { or } \\
\text { ramped cyclic } \\
\text { loading starting } \\
\text { at } 0.5 \mathrm{MPa} \text {, } \\
\text { increase by } \\
0.5 \mathrm{MPa} / \mathrm{d}\end{array}$ & $0 \mathrm{ng} / \mathrm{mL}$ & $\begin{array}{l}\text { COL1A1 and SOX9 expression } \\
\text { increase under both loading } \\
\text { regimes. } \\
\text { No collagen type II and aggrecan } \\
\text { expression. }\end{array}$ \\
\hline $\begin{array}{l}\text { Maxson and } \\
\text { Burg, } 2012\end{array}$ & $\begin{array}{l}\text { Murine bone } \\
\text { marrow MSCs }\end{array}$ & $\begin{array}{l}\text { Scaffold } \\
\left(2 \times 10^{6} \text { cells/ }\right. \\
\mathrm{mL} ; 2 \% \\
\text { agarose })\end{array}$ & $\begin{array}{l}\text { Cyclic, } 300 \mathrm{kPa} \text {, } \\
0.5 \mathrm{~Hz}, 0.7 \mathrm{~mL} / \\
\text { min medium } \\
\text { perfusion }\end{array}$ & $\begin{array}{c}\text { Conditioned } \\
\text { medium from } \\
\text { chondrogenic } \\
\text { MSCs, } \\
\text { no TGF- } \beta \\
\text { application } \\
\text { under load }\end{array}$ & $\begin{array}{c}\text { SOX9, COL2A1 and ACAN increased } \\
\text { expression under pressure. } \\
\text { More GAG synthesis under } \\
\text { mechanical load with increased } \\
\text { TGF- } \beta \text { secretion. }\end{array}$ \\
\hline $\begin{array}{l}\text { Vinardell et al., } \\
2012\end{array}$ & $\begin{array}{c}\text { Porcine } \\
\text { synovium } \\
\text { membrane } \\
\text { MSCs and } \\
\text { infrapatellar fat } \\
\text { pad MSCs }\end{array}$ & Pellets & $\begin{array}{c}\text { Cyclic, } 10 \mathrm{MPa}, \\
1 \mathrm{~Hz}, 4 \mathrm{~h} / \mathrm{d} \\
2 \text { weeks }\end{array}$ & $0,1,10 \mathrm{ng} / \mathrm{mL}$ & $\begin{array}{l}\text { SOX9, ACAN, COL2A1 expression } \\
\text { upregulated in the presence of } \\
\text { TGF- } \beta \text {. } \\
\text { GAG synthesis increases upon } \\
\text { loading in the presence of } 1 \mathrm{ng} / \\
\text { mL TGF- } \beta \text {. No effect on collagen } \\
\text { synthesis. } \\
\text { No increase in endogenous TGF- } \beta \\
\text { production or TGF- } \beta \text { receptor II } \\
\text { expression. }\end{array}$ \\
\hline $\begin{array}{c}\text { Puetzer et al., } \\
2013\end{array}$ & $\begin{array}{l}\text { Human } \\
\text { adipose MSCs } \\
\text { and bone } \\
\text { marrow MSCs }\end{array}$ & $\begin{array}{l}\text { Scaffold } \\
\left(9 \times 10^{6} \text { cells/ }\right. \\
\text { mL; } 2 \% \\
\text { agarose })\end{array}$ & $\begin{array}{l}\text { Cyclic, } 7.5 \mathrm{MPa}, \\
1 \mathrm{~Hz}, 4 \mathrm{~h} / \mathrm{d} \\
21 \mathrm{~d} \text { loading }\end{array}$ & $0 \mathrm{ng} / \mathrm{mL}$ & $\begin{array}{l}\text { SOX9, ACAN and COMP expression } \\
\text { upregulated upon loading but no } \\
\text { expression after } 14 \text { and } 21 \mathrm{~d} .\end{array}$ \\
\hline
\end{tabular}

control this response have been examined in a few studies (Fig. 2).

Cell surface receptors, membrane channels and downstream signalling

Mechanotransduction involves transfer of the mechanical force (e.g. compressive, tensile or hydrostatic pressure) into a signal through cell surface receptors or membrane channels during biomechanical stimulation. Few studies have examined how mechanotransduction of hydrostatic loading occurs. Due to the presence of TGF- $\beta$, TGF- $\beta$ receptor I and II may have an influence on pressurestimulated chondrogenesis with the canonical TGF- $\beta$ / SMAD pathway being a candidate downstream pathway (reviewed by Cleary et al., 2015). TGF- $\beta$ stimulates phosphorylation of SMAD2 and SMAD3 and this, subsequently, leads to nucleus translocation and regulation of chondrogenic genes (SOX9, COL2A1, ACAN). However, inhibition of TGF- $\beta$ receptor I only partially inhibits the anabolic response caused by hydrostatic pressure, indicating that other pathways are involved (Li et al., 2012). Non-canonical SMAD pathways have also been investigated due to their association with TGF- $\beta$-induced chondrogenesis; specifically, mitogen-activated protein (MAP) kinases including extracellular-regulated protein kinase-1 (ERK1), p38 and c-Jun N-terminal kinases (JNK) (Li et al., 2009; Sakao et al., 2008; Zhao et al., 2016; Zhao et al., 2015). Sakao et al. (2008) reported that application of hydrostatic pressure in the presence of ERK and p38 inhibitors does not inhibit expression of $S O X 9, C O L 2 A 1$ and proteoglycan core protein but addition of a JNK inhibitor prevents upregulation of these genes. Recent investigations have shown that hydrostatic pressure enhances phosphorylated JNK expression, leading to subsequent increases in SOX9, COL2A1 and ACAN expression (Zhao et al., 2015).

Integrins are transmembrane proteins composed of $\alpha$ and $\beta$ sub-units that mediate cell-extracellular matrix interactions (Loeser, 2014). Integrin binding of cells to the extracellular matrix may facilitate 
mechanotransduction of mechanical forces applied to cartilage (Docheva et al., 2014; Loeser, 2014). Steward et al. (2014), using an RGDS peptide as an integrinbinding inhibitor, showed that the beneficial effects of hydrostatic pressure are inhibited in its presence. However, RGDS is a broad integrin inhibitor and the specific integrin sub-units involved were not evaluated. There are no reports of hydrostatic pressure studies with inhibition or knock-down of specific integrins to understand their specific contributions to mechanotransduction.

Oestrogen has been implicated in chondrogenesis and $\mathrm{OA}$, as studies have described a higher prevalence of OA in female patients who are going through menopause and have reduced levels of oestrogen (Richette et al., 2003). Replacement therapy may reduce cartilage loss but there have been conflicting results (Sahyoun et al., 1999; Wluka et al., 2001). Hydrostatic pressure upregulates oestrogen receptor $(\mathrm{ER} \alpha)$ activity during MSC chondrogenesis, whilst application of $17 \beta$-oestradiol $\left(E_{2}\right)$, combined with pressure, enhances matrix synthesis (Fig. 2a) (Zhao et al., 2016). However, tamoxifen (ER $\alpha$ inhibitor) application reduces chondrogenic gene expression and GAG content upon stimulation, although it has no effect on unloaded controls. Downstream of ER $\alpha$ activation, mitogen-activated protein kinase (MAPK) pathway and, specifically, JNKs are phosphorylated under pressure and contribute to the anabolic response. In the presence of tamoxifen, JNK is not phosphorylated under pressure, indicating that this is a downstream target of pressure-induced chondrogenesis (Zhao et al., 2016). However, other downstream targets of ER $\alpha$ have yet to be elucidated.

Membrane channels that allow the movement of molecules both in and out of cells and between cells, altering the osmotic pressure during hydrostatic loading have been studied in chondrocytes (Hall, 1999). The author demonstrated that cation transporters $(\mathrm{Na} / \mathrm{K} / 2 \mathrm{Cl}$ and $\mathrm{Na} / \mathrm{K}$ pumps) are inhibited in chondrocytes under hydrostatic pressure ranging from $0.1-10 \mathrm{MPa}$, indicating that other channels may be involved in increasing matrix synthesis under pressure for articular-cartilage chondrocytes. In the case of MSC chondrogenesis under the influence of hydrostatic pressure, studies have primarily focussed on channels involved in purinergic and calcium signalling. Stretch-activated calcium channels and voltage-gated calcium channels have been implicated in the mechanotransduction process. Stretch-activated channels are induced by different types of mechanical loading, including hydrostatic pressure (Mizuno, 2005; Mobasheri et al., 2002), whereas voltage-gated calcium channels are activated through membrane depolarisation and mediate calcium influx. In the latter case, calcium movement through these channels increases cellular calcium concentration directly or indirectly from calcium released from sarcoendoplasmic reticulum calcium stores (SERCs). Downstream, calcium initiates the activity of secondary messengers (e.g. calmodulin, calmodulin kinase type II and calcineurin) that leads to a variety of cascades to be activated, particularly chondrogenic gene expression (Knight et al., 2009; Steward et al., 2014). These messengers are initiated under compressive and fluid flow mechanotransduction in MSCs and chondrocytes (Mizuno, 2005; Mobasheri et al., 2002).

Hydrostatic pressure applied during MSC chondrogenesis induces an anabolic response through voltage-gated ion channels, as inhibition prevents pressure-induced matrix synthesis, whereas inhibiting stretch-activated channels do not prevent the anabolic effect of pressure (Steward et al., 2014). Use of a calcium chelator preventing intracellular calcium movement, also significantly reduces GAG and collagen synthesis upon pressure stimulation (Steward et al., 2014). Thus, membrane depolarisation and calcium mobilisation are a mechanism of pressure-stimulated cartilage formation. However, the exact reason for how voltage-gated ion channels are involved in the hydrostatic pressure response requires further investigation.

A candidate pathway involved in this process and that utilises voltage-gated ion channels is the purinergic signalling. This involves hemichannels, which are membrane proteins consisting of connexins that form gap junctions and enable cellcell communication (Millward-Salder et al., 2004; Knight et al., 2009). Upon mechanical stimulation, MSCs release ATP and this extracellular release through hemichannels enables it to bind to the purine receptors $\mathrm{P} 2 \mathrm{X}$ or $\mathrm{P} 2 \mathrm{Y}$. $\mathrm{P} 2 \mathrm{X}$ receptor is an ATP-gated ion channel and P2Y receptors are coupled to G-proteins to elicit a calcium response through inositol-triphosphate-mediated release from sarcoendoplasmic reticulum stores (SERCs) (Fig. 2b). The increased calcium concentration depolarises the membrane and amplifies the signal through activation of the voltage-gated ion channels and calcium release from intracellular stores (Steward et al., 2014a). The authors demonstrated that inhibition of SERCs also inhibits the anabolic effects of hydrostatic pressure on MSC chondrogenesis.

Steward et al. (2016) studied the purinergic signalling pathway in more detail to understand its importance during hydrostatic pressure chondrogenesis. Pressure activates the pathway, as indicated by increased extracellular ATP production. However, inhibition of hemichannels, P-receptors or extracellular ATP blocks the anabolic response upon pressure stimulation, indicating its importance during pressure-induced signalling. Addition of exogenous ATP without pressure does not reproduce this behaviour, thus showing the importance of hydrostatic pressure for purinergic signalling and that other upstream mechanisms are stimulated to upregulate chondrogenic gene expression and matrix production. These latter studies suggest differences in the mechanotransduction of hydrostatic pressure versus compressive and multiaxial loading regimes. 
Table 3a. Summary of the effects of hydrostatic pressure on pre-differentiated chondrogenic MSCs.

\begin{tabular}{|c|c|c|c|c|c|}
\hline Publication & Cell source & Pellets/scaffold & Loading regime & $\begin{array}{l}\text { Pre- } \\
\text { differentiation } \\
\text { period } \\
\end{array}$ & Principal findings \\
\hline $\begin{array}{c}\text { Luo and } \\
\text { Seedhom, } 2007\end{array}$ & $\begin{array}{l}\text { Ovine bone } \\
\text { marrow MSCs }\end{array}$ & $\begin{array}{c}\text { Scaffold } \\
\left(5 \times 10^{5} \text { cells } / \mathrm{mL},\right. \\
\text { plasma-treated } \\
\text { polyester })\end{array}$ & $\begin{array}{c}\text { Cyclic, } 0.1 \mathrm{MPa} \text {, } \\
0.25 \mathrm{~Hz} \\
30 \mathrm{~min} / \mathrm{d}, 10 \mathrm{~d} \\
\text { culture } \\
\end{array}$ & $28 d$ & $\begin{array}{l}\text { DNA, GAG and collagen } \\
\text { content increase significantly. }\end{array}$ \\
\hline Li et al., 2009 & $\begin{array}{c}\text { Rat bone } \\
\text { marrow MSCs }\end{array}$ & $\begin{array}{c}\text { Scaffold } \\
{\left[4 \times 10^{6} \mathrm{cells}\right.} \\
\text { in } 1.5 \%(\mathrm{w} / \mathrm{v}) \\
\text { alginate beads }]\end{array}$ & $\begin{array}{l}\text { Cyclic, 14- } \\
36 \mathrm{kPa}, 0.25 \mathrm{~Hz} \\
1 \mathrm{~h} / \mathrm{d}, 7 \mathrm{~d} \\
\text { loading }\end{array}$ & $7 \mathrm{~d}$ & $\begin{array}{c}\text { SOX9, COL2A1 and ACAN } \\
\text { expression stimulated by } \\
\text { loading only - elevated in the } \\
\text { presence of TGF- } \beta \text {. } \\
\text { p38 MAP kinase stimulated by } \\
\text { loading, elevated and enhanced } \\
\text { in the presence of TGF- } \beta \text { - only } \\
\text { partially suppressed loading } \\
\text { response in the presence of } \\
\text { inhibitor. }\end{array}$ \\
\hline $\begin{array}{l}\text { Meyer et al., } \\
2011\end{array}$ & $\begin{array}{l}\text { Porcine bone } \\
\text { marrow MSCs }\end{array}$ & $\begin{array}{l}\text { Scaffold } \\
\left(15 \times 10^{6} \text { cells } /\right. \\
\text { mL; } 2 \% \\
\text { agarose })\end{array}$ & $\begin{array}{c}\text { Cyclic, } 10 \mathrm{MPa} \text {, } \\
1 \mathrm{~Hz}, 4 \mathrm{~h} / \mathrm{d}, \\
5 \mathrm{~d} / \text { week for } 5 \\
\text { weeks } \\
\text { Continuous (0- } \\
42 \mathrm{~d} \text { ) } \\
\text { Delayed (22- } \\
42 \mathrm{~d} \text { and no } \\
\text { TGF- } \beta \text { ) } \\
\end{array}$ & $21 \mathrm{~d}$ & $\begin{array}{l}\text { Continuous loading increases } \\
\text { dynamic modulus, delayed } \\
\text { loading has no effect - increased } \\
\text { matrix synthesis in core under } \\
\text { loading. }\end{array}$ \\
\hline Li et al., 2012 & $\begin{array}{c}\text { Rat bone } \\
\text { marrow MSCs }\end{array}$ & $\begin{array}{c}\text { Scaffold } \\
{\left[5 \times 10^{6} \text { cells }\right.} \\
\text { in } 1.5 \%(\mathrm{w} / \mathrm{v}) \\
\text { alginate beads }]\end{array}$ & $\begin{array}{l}\text { Cyclic, 14- } \\
36 \mathrm{kPa}, 0.25 \mathrm{~Hz}, \\
1 \mathrm{~h} / \mathrm{d}, 7 \mathrm{~d} \\
\text { loading }\end{array}$ & $7 \mathrm{~d}$ & $\begin{array}{c}\text { SOX9, ACAN, COL2A1, RUNX2 } \\
\text { and IHH expression upregulated } \\
\text { upon loading with or without } \\
\text { TGF- } \beta \text {. } \\
\text { GAG and collagen II synthesis } \\
\text { increased upon loading, } \\
\text { independently of TGF- } \beta \\
\text { presence - synergistic effect in } \\
\text { its presence. } \\
\text { Endogenous TGF- } \beta \text { production } \\
\text { stimulated under loading. } \\
\text { Canonical TGF- } \beta / \text { SMAD } \\
\text { pathway not solely involved in } \\
\text { pressure-induced chondrogenic } \\
\text { response. }\end{array}$ \\
\hline Liu et al., 2012 & $\begin{array}{l}\text { Human } \\
\text { infrapatellar fat } \\
\text { pad MSCs }\end{array}$ & $\begin{array}{l}\text { Pellet culture; } \\
\text { scaffold } \\
{\left[20 \times 10^{6} \text { cells }\right.} \\
\text { in } 2 \%(\mathrm{w} / \mathrm{v}) \\
\text { agarose] } \\
5 \% \text { oxygen } \\
\text { physioxic } \\
\text { preconditioning }\end{array}$ & $\begin{array}{l}\text { Cyclic, } 10 \mathrm{MPa}, \\
1 \mathrm{~Hz}, 2 \mathrm{~h} / \mathrm{d}, 5 \mathrm{~d} / \\
\text { week }\end{array}$ & $14 \mathrm{~d}$ & $\begin{array}{l}\text { No enhancement in matrix } \\
\text { synthesis but mechanical } \\
\text { stiffness increases after loading. }\end{array}$ \\
\hline
\end{tabular}

\section{Microenvironment and cytoskeletal regulation}

Mechanotransduction signals require cytoskeletal changes to transduce the mechanical response. In this regard, the microenvironment surrounding the cells modulates the mechanoresponse and has been investigated under hydrostatic pressure (Steward et al., 2012; Steward et al., 2013; Zhao et al., 2015). Steward et al. (2012) compared the hydrostatic pressure response between cells encapsulated within agarose and fibrin hydrogels. Initially, MSCs within agarose have a rounded morphology due to no direct interactions, whilst in fibrin they adopt a fibroblastic morphology through integrin-receptor- mediated connections. The differing interactions alter matrix elaboration during chondrogenesis whereby increased GAG synthesis is observed within agarose, whilst collagen synthesis is enhanced in fibrin. Upon application of hydrostatic pressure, only fibrinencapsulated MSCs appear to increase GAG and collagen II synthesis. As previously discussed, this response is partially mediated by integrins, since their inhibition lead to loss in this beneficial effect under pressure stimulation (Steward et al., 2012).

In a follow-up study, Steward et al. (2013) examined the effect of substrate or scaffold stiffness on pressure-stimulated MSC chondrogenesis. Under unloaded conditions, MSCs in stiffer hydrogels (4\% 
Table 3b. Summary of the effects of hydrostatic pressure on pre-differentiated chondrogenic MSCs.

\begin{tabular}{|c|c|c|c|c|c|}
\hline Publication & Cell source & Pellets/scaffold & Loading regime & $\begin{array}{c}\text { Pre- } \\
\text { differentiation } \\
\text { period }\end{array}$ & Principal findings \\
\hline $\begin{array}{l}\text { Safshekan et al., } \\
2012\end{array}$ & $\begin{array}{c}\text { Human adipose } \\
\text { MSCs }\end{array}$ & Pellet & $\begin{array}{l}\text { Cyclic, } 5 \mathrm{MPa} \text {, } \\
0.5 \mathrm{~Hz}, 4 \mathrm{~h} / \mathrm{d} \\
7 \mathrm{~d} \text { loading } \\
( \pm \mathrm{TGF}-\beta)\end{array}$ & $4 \mathrm{~d}$ & $\begin{array}{l}\text { SOX9 and COL2A1 expression } \\
\text { increased in the presence of } \\
\text { TGF- } \beta \text { and loading. } \\
\text { ACAN expression increased } \\
\text { with pressure alone, synergistic } \\
\text { effect combined with TGF- } \beta \text {. }\end{array}$ \\
\hline $\begin{array}{c}\text { Karkhaneh et al., } \\
2014\end{array}$ & $\begin{array}{l}\text { Rabbit bone } \\
\text { marrow MSCs }\end{array}$ & $\begin{array}{c}\text { Scaffold } \\
{\left[2 \times 10^{5} \text { cells/ }\right.} \\
\text { scaffold on either } \\
\text { polycaprolactone } \\
(\mathrm{PCL}) / \text { polyvinyl } \\
\text { alcohol (PVA) or } \\
\text { gelatine-PCL- } \\
\text { PVA scaffolds }] \\
\end{array}$ & $\begin{array}{c}\text { Cyclic, } 5 \mathrm{MPa}, \\
0.5 \mathrm{~Hz}, 2 \mathrm{~s} / \mathrm{d}, 7 \mathrm{~d} \\
\text { loading }\end{array}$ & 7 and $21 \mathrm{~d}$ & $\begin{array}{l}\text { COL2A1 expression increases } \\
\text { upon loading; no change in } \\
\text { SOX9 or ACAN expression. } \\
\text { GAG synthesis increases under } \\
\text { loading in PCL-PVA scaffolds } \\
\text { and decreases on gelatine-PCL- } \\
\text { PVA scaffolds. }\end{array}$ \\
\hline $\begin{array}{l}\text { Hosseini et al., } \\
2015\end{array}$ & $\begin{array}{l}\text { Human bone } \\
\text { marrow and } \\
\text { adipose MSCs }\end{array}$ & $\begin{array}{c}\text { Scaffold } \\
\left(86,500 \text { cells } / \mathrm{cm}^{2},\right. \\
\text { rubber silicone })\end{array}$ & \begin{tabular}{|c|} 
Cyclic, $3 \mathrm{MPa}$, \\
$0.5 \mathrm{~Hz}, 1 \mathrm{~h} / \mathrm{d}$ for \\
$3 \mathrm{~d}$ combined \\
with shear \\
stress $(0.2 \mathrm{~Pa}$, \\
$1 \mathrm{~Hz})$, no TGF- $\beta$ \\
\end{tabular} & $18 \mathrm{~d}$ & $\begin{array}{c}\text { SOX9, ACAN and COL2A1 } \\
\text { expression enhanced under } \\
\text { combined loading in both MSC } \\
\text { sub-types. }\end{array}$ \\
\hline Li et al., 2016 & $\begin{array}{l}\text { Rabbit cartilage } \\
\text { progenitor cells, } \\
\text { infrapetallar fat } \\
\text { pad MSCs }\end{array}$ & $\begin{array}{c}\text { Scaffold (alginate } \\
\text { beads) }\end{array}$ & $\begin{array}{c}\text { Cyclic, } 5 \mathrm{MPa} \text {, } \\
0.5 \mathrm{~Hz}, 4 \mathrm{~h} / \mathrm{d}\end{array}$ & $7 \mathrm{~d}$ & $\begin{array}{l}\text { SOX9, ACAN and COL2A1 } \\
\text { expression upregulated in both } \\
\text { cell types after } 2 \text { and } 4 \text { week } \\
\text { loading - increased matrix } \\
\text { synthesis. }\end{array}$ \\
\hline Zhao et al., 2016 & $\begin{array}{c}\text { Rat bone } \\
\text { marrow MSCs }\end{array}$ & $\begin{array}{c}\text { Scaffold } \\
{\left[4 \times 10^{6} \text { cells }\right.} \\
\text { in } 1.5 \%(\mathrm{w} / \mathrm{v}) \\
\text { alginate beads }]\end{array}$ & $\begin{array}{c}\text { Cyclic: } 14- \\
36 \mathrm{kPa}, 0.25 \mathrm{~Hz}, \\
1 \mathrm{~h} / \mathrm{d} \text {. Static: } \\
20 \mathrm{kPa}, 7 \mathrm{~d} \\
\text { loading }\end{array}$ & $7 \mathrm{~d}$ & $\begin{array}{c}\text { SOX9 expression increases } \\
\text { under loading, COLXA1 } \\
\text { expression and matrix staining } \\
\text { are reduced. }\end{array}$ \\
\hline
\end{tabular}

agarose) produce less extracellular matrix than in softer hydrogels (1\%). Application of hydrostatic pressure results in enhanced chondrogenic gene expression and matrix synthesis with increasing hydrogel stiffness. The authors investigated the changes in cytoskeletal elements under pressure, as alterations in these structures relate to cell morphology and shape that are influenced by the surrounding environment and stimuli. Indeed, previous studies have indicated that prevention of F-actin polymerisation induces chondrogenesis through development of a rounded cell shape (Daniels and Solursh, 1991; Daniels and Sandra, 1990; Woods et al., 2005). Steward et al. (2013) demonstrated that within stiff hydrogels, more actin development is observed in unloaded controls, leading to a reduced chondrogenic response as compared to that found for cells in softer gels. Examination of vimentin (intermediate microfilament), tubulin (microtubule) and vinculin (focal adhesion molecule involved in anchorage to actin cytoskeleton) shows that vimentin staining become more diffuse upon loading application, whereas the other elements do not alter their structure (Fig. 2c). The authors suggested that this diffuse staining may be related to the process of depolymerisation due to pressurisation and that vimentin is more sensitive to hydrostatic pressure as compared with other cytoskeletal elements. siRNA knockdown of vimentin within MSCs results in inhibited cartilage matrix production (Bobick et al., 2010). Furthermore, vimentin interacts with actin and the integrins $\alpha v \beta_{3}$ and $\alpha_{2} \beta_{1}$, indicating a potential mechanotransduction pathway that requires further elucidation (Steward et al., 2013).

In relation to these phenomena, the development and presence of the pericellular matrix plays an important role in hydrostatic pressure mechanotransduction response and cytoskeletal behaviour. Application of the integrin inhibitor RGDS to stiff hydrogels in an unloaded situation results in more diffusive vimentin staining, leading to increased chondrogenic matrix production as compared with untreated controls (Steward et al., 2013). However, in combination with hydrostatic pressure, vimentin do not alter its structure in the presence of RGDS, thus blocking the anabolic effects of hydrostatic pressure. This indicates the importance of both vimentin and upstream integrins and receptor channels to transduce the pressure-induced signal through the pericellular matrix.

In relation to the cytoskeletal changes, the role of GTPases has been investigated under hydrostatic pressure (Zhao et al., 2015). GTPases perform an important role in cytoskeletal regulation within cells. RhoA via Rho-kinase (ROCK) plays a critical role in actin organisation and promotes a spindle-shaped 
morphology in MSCs while inhibition of RhoA/ ROCK signalling promotes chondrogenesis (Woods and Beier, 2006; Woods et al., 2005). A member of the GTPase family that is involved in chondrogenesis is Rac1. Rac1 inhibition reduces MSC condensation during the early stages of chondrogenesis through related expression of cell-adhesion genes and proteins, N-cadherins. This subsequently leads to reduced chondrogenic gene expression and matrix production. In contrast, overexpression of Rac1 results in higher $\mathrm{N}$-cadherin gene expression and subsequent chondrogenic gene expression, thus demonstrating its importance during the early stages of MSC cartilage differentiation (Woods et al., 2007). Zhao et al. (2015) examined the role of RhoA and Rac1 in MSC chondrogenesis under the influence of hydrostatic pressure. In the presence of a RhoA agonist, the beneficial effects of pressure on chondrogenic gene expression and GAG deposition are inhibited. In contrast, in the presence of a RhoA inhibitor, hydrostatic pressure induces a significant increase in both gene expression and matrix formation (Fig. 2a). Use of a Rac1 inhibitor significantly inhibits anabolic response under pressure, whereas use of a Rac1 agonist enhances chondrogenesis. This indicates a primary role of Rac1 in pressure-induced chondrogenesis. The study did not investigate the relationship between Rac1 and cytoskeletal elements or upstream G-protein coupled receptors (GPCRs) involved in this anabolic response but it can be postulated that actin reorganisation through Rac1 and alterations in vimentin structure results in enhanced chondrogenesis under hydrostatic pressure.
Candidates for future analysis: membrane-bound receptors, ion channels, primary cilia and nuclei

The integrin family of receptors is involved in hydrostatic pressure chondrogenesis, both with respect to initial signal transduction and in its interaction with vimentin, although no specific integrin was investigated by Steward et al. (2013). An integrin expressed during MSC chondrogenesis is $\alpha_{10} \beta_{1}$. This is one of the principal collagenbinding receptors, alongside $\alpha_{1^{\prime}} \alpha_{2}$ and $\alpha_{11}$. During MSC chondrogenesis, $\alpha_{10}$ increases in correlation with collagen II synthesis, whilst $\alpha_{11}$ decreased. Furthermore, application of basic fibroblastic growth factor 2 (FGF2) to MSCs in monolayer increases $\alpha_{10}$ expression and this, subsequently, upregulates collagen II gene expression during chondrogenesis (Lundgren-Akerlund and Aszodi, 2014). However, whether $\alpha_{10}$ is involved in mechanical stimulation, specifically under hydrostatic pressure, remains to be elucidated (Bengtsson et al., 2005; LundgrenAkerlund and Aszodi, 2014; Varas et al., 2007). Furthermore, recent investigations have also implicated $\alpha_{8}$ integrin in MSC chondrogenesis (LaPointe et al., 2013). Thus, insights into specific integrins and how they are influenced under pressure is an area for future studies (Fig. 3a).

The plasmalemma contains ion channels that are potentially involved in mechanotransduction signalling cascade (reviewed by Lewis and BarrettJolley, 2015). One set of ion channels that has been studied are the transient receptor potential vanilloid (TRPV) channels (reviewed by Krupkova et al., 2017).
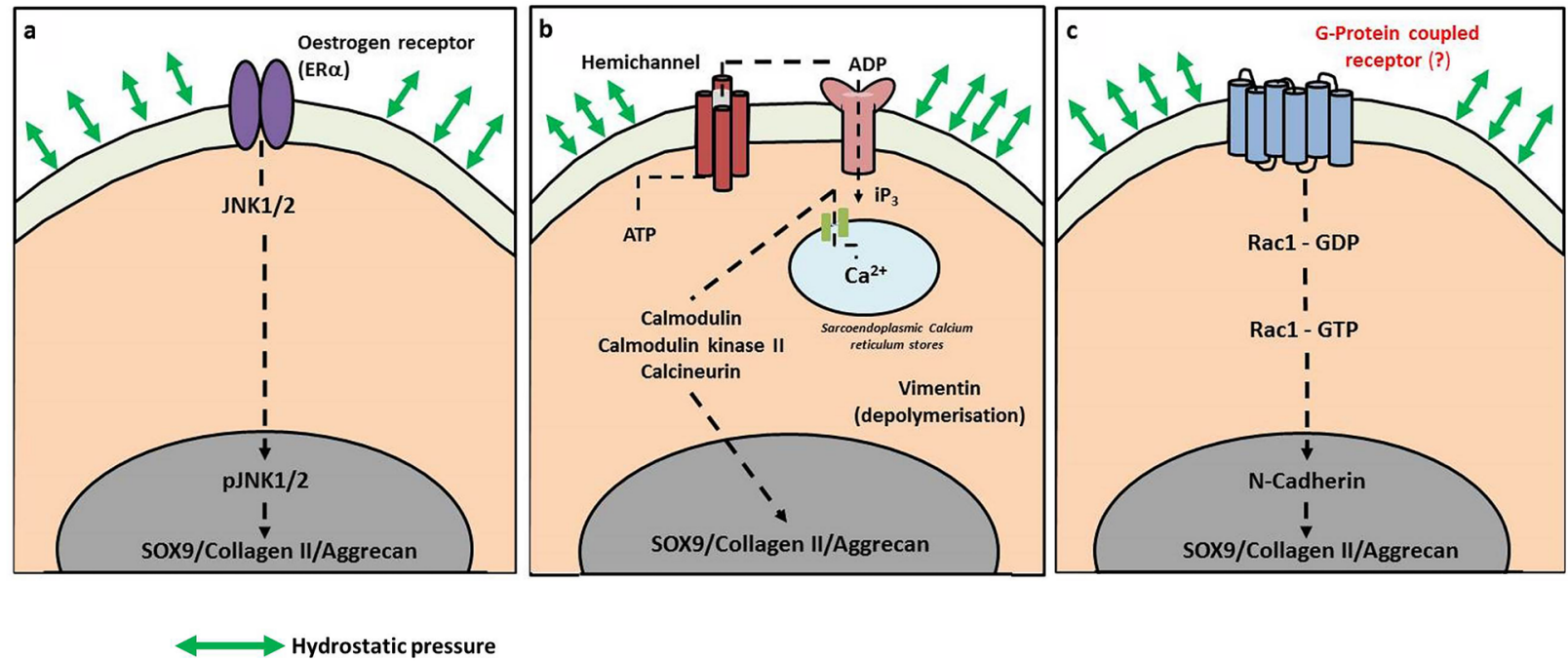

Fig. 2. Schematic diagrams summarising the pathways under the influence of hydrostatic pressure during MSC chondrogenesis that have been examined in previous publications. (a) Pressure upregulates oestrogen receptor in MSC chondrogenesis and the oestrogen receptor pathway exerts its anabolic response via JNK. Voltage-gated calcium ion channels and calcium stores (SERCs) are activated under hydrostatic loading via (b) purinergic signalling that stimulates calcium signalling via ATP release from hemichannels and interaction with cellular purine receptors, e.g. P2X and P2Y. Pressure-stimulated chondrogenesis influences the cytoskeletal structure via GTPases, specifically (c) Rac1-GTPase induces the anabolic response under pressure via activation of N-caderins, with MSC condensations and subsequent chondrogenesis. 
Murumatsu et al. (2007) demonstrated that transient receptor potential cation channel subfamily $\mathrm{V}$ member 4 (TRPV4) directly influences chondrogenic genes via SOX9 expression, as use of a TRPV4 antagonist reduces SOX9 expression and prevents MSC chondrogenesis. In addition, the authors demonstrated the importance of calcium signalling in TRPV4 activation, as use of either a calcium chelator or calmodulin inhibitor prevents SOX9 expression and subsequent chondrogenesis (Muramatsu et al., 2007). In articular-cartilage chondrocytes, stimulation of TRPV4 under hypoosmotic stress increases chondrogenic gene expression and matrix accumulation (GAG and collagen content). However, the presence of a TRPV4 inhibitor (GSK205) reduces both osmotic-stressed-induced matrix accumulation and calcium signalling (O'Conor et al., 2014; Phan et al., 2009). Interestingly, an interaction between $\alpha_{1} \beta_{1}$ integrin and TRPV4 has been demonstrated under osmotic stress in chondrocytes, whereby loss of the integrin prevents transduction of signalling via TRPV4 (Jablonski et al., 2014). Furthermore, TRPV4 knock-out mouse models show that despite reduced severity in ageing-associated OA, TRPV4 deficiency still results in premature OA and, thus, its presence is critical for cartilage homeostasis, whilst also being a potential OA marker (Clark et al., 2010; Lamande et al., 2011; O'Conor et al., 2016). In the context of hydrostatic pressure, due to the force resulting from fluid pressurisation being applied, there is an osmotic stress exerted on cells that varies between hypo and hyperosmotic stress, especially under cyclic hydrostatic pressure. How TRPV4 and other TRP channels are involved under pressure remains an area to be investigated (Fig. 3b).

A further set of receptors that may be under the influence of hydrostatic pressure are the GPCRs. GPCRs are stimulated under mechanical loading, although it is unknown whether they are involved in hydrostatic pressure mechanotransduction (reviewed

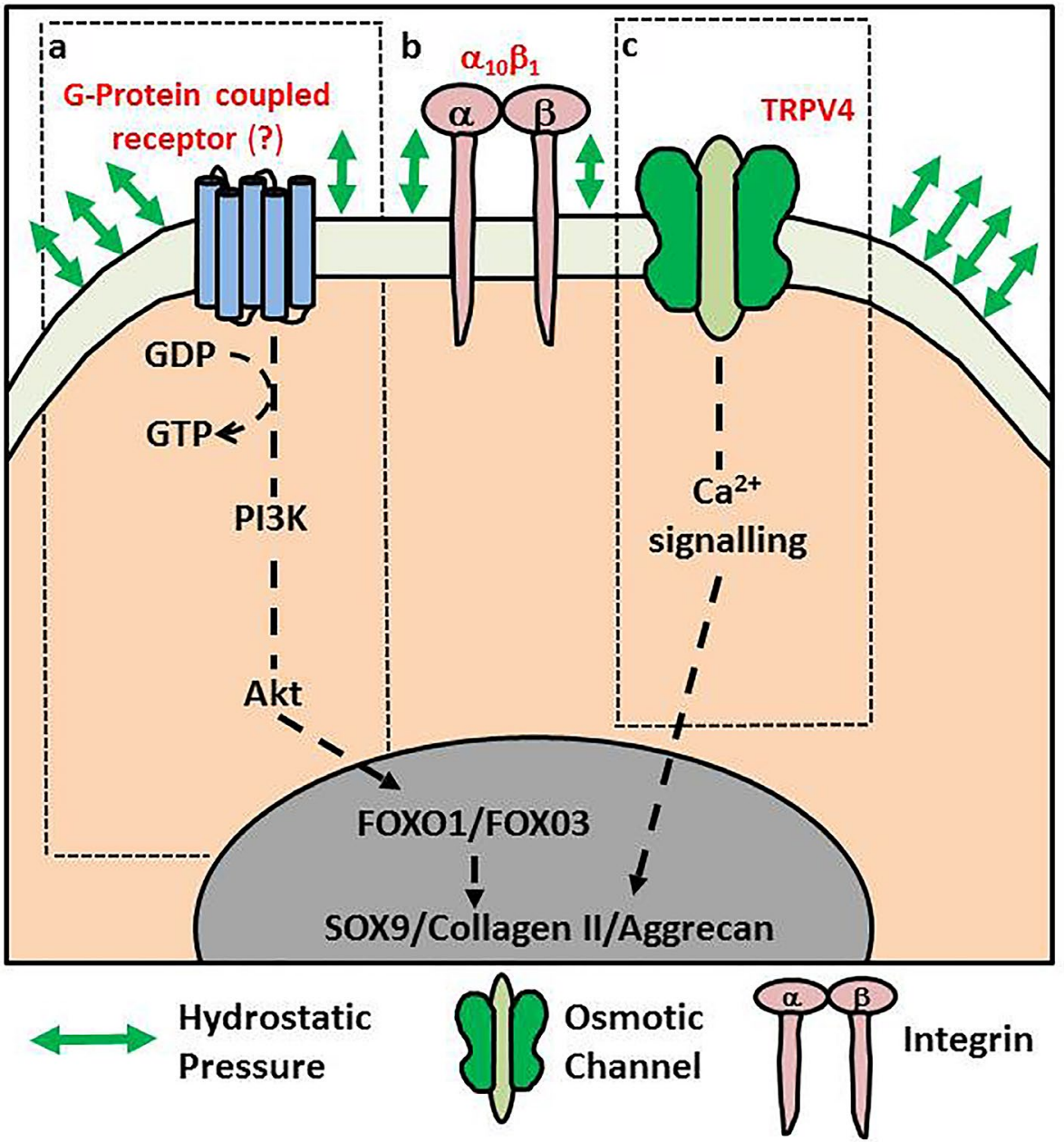

Fig. 3. Schematic diagram showing hypothetical receptors and channels that could be under the influence of hydrostatic pressure. (a) Integrin $\alpha_{10} \beta_{1}$ increase in expression during MSC chondrogenesis and its stimulation under pressure have yet to be elucidated. (b) Due to hydrostatic pressure involving fluid pressurisation, osmotic channels may be implicated in the process; (c) specifically, TRPV4 is a potential membrane channel stimulated by hydrostatic pressure during MSC chondrogenesis, exerting its response via downstream calcium signalling. The G-protein-coupled receptors are stimulated under mechanical load, although not directly implicated under hydrostatic pressure. The downstream PI3K/Akt/FOXO pathway is potentially activated, thus, preventing chondrogenic hypertrophy under these conditions. 
by Shah et al., 2014). Studies have described the prevention of hypertrophy under pressure, although the pathways influencing this outcome were not demonstrated. Interestingly, studies have described the activation of the downstream GPCR pathway, phosphoinositide 3-kinase/Akt/forkhead box protein $\mathrm{O}$ (PI3K/Akt/FOXO). This signalling mechanism is involved in preventing hypertrophy in MSC chondrogenesis (Lee et al., 2013). Furthermore, recent investigations implicated the FOXO transcription factors in preventing OA-associated cartilage damage (Akasaki et al., 2014; Matsuzaki et al., 2018). Whether this downstream GPCR pathway and its respective receptor is stimulated under hydrostatic pressure is not known (Fig. 3c).

Recent studies in articular-cartilage chondrocytes have also begun to investigate the role of the primary cilium in mechanotransduction (Bodle and Loboa, 2016; Knight et al., 2009; McGlashan et al., 2006; Phan et al., 2009; Wann et al., 2012). The cilium is a membrane-coated axoneme that emanates from the cell surface into the cell microenvironment and its loss leads to skeletal abnormalities (Bodle and Loboa, 2016). Under compressive loading, the cilium is involved in the activation of ATP-induced calcium signalling in articular cartilage chondrocytes, although it is not the initial mechanoresponder during this process (Wann et al., 2012). In relation to potential hydrostatic pressure-stimulated channels, TRPV4 colocalises on the cilium and cell membrane of porcine chondrocytes. Interestingly, TRPV4mediated calcium signalling requires the presence of an intact cilium, even in the presence of a TRPV4 activator and hypo-osmotic loading (Phan et al., 2009).

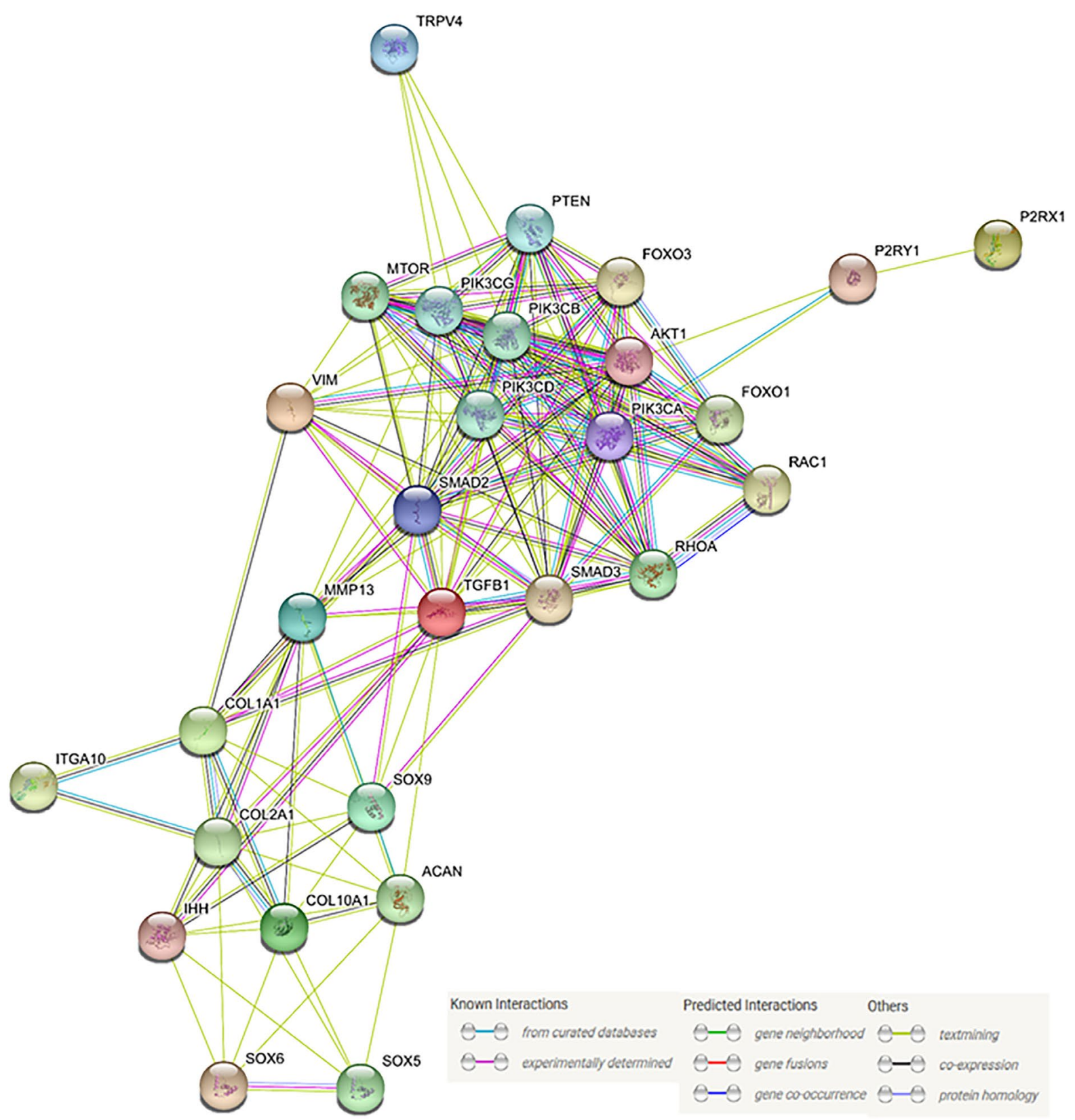

Fig. 4. STRING database analysis based on genes and proteins under the influence of hydrostatic pressure and chondrogenesis, showing interactions among proteins based on database analysis. 
Integrins $\left(\alpha_{2}, \alpha_{3}\right.$ and $\left.\beta_{1}\right)$ and connexins are also found on chondrocyte cilia (Knight et al., 2009; McGlashan et al., 2006). Thus, rather than the membrane-bound receptors and ion channels, the cilium may be the initial mechano-sensor for certain types of loading, potentially hydrostatic pressure. However, since the primary cilium can act as a pressure sensor under compressive and tensile loading, it is unlikely to be an influence under hydrostatic pressure due to minimal fluid flow that prevents bending of the cilium (Bell, 2008). Based on the present review, it may also be hypothesised that due to the presence of the receptors and ion channels, the cilium may be indirectly activated and act as an initial mechanosensor under hydrostatic pressure. No studies have described the involvement of the cilium in pressure-induced MSC chondrogenesis; therefore, further elucidation is required.
Researchers have also begun to examine the nucleus and its roles during mechanical loading. Studies have begun to show that the nucleus acts as a mechanosensor upon stimulation, under compressive and tensile loading (Heo et al., 2018; Martins et al., 2012). However, whether the nucleus can act as a mechanosensor under hydrostatic pressure when there is no direct cellular deformation needs to be established.

\section{Discussion}

Hydrostatic pressure has an anabolic effect on MSC chondrogenesis, whereby it increases cartilage gene expression (SOX9, COL2A1, ACAN) and matrix formation (GAG and collagen II). However, there

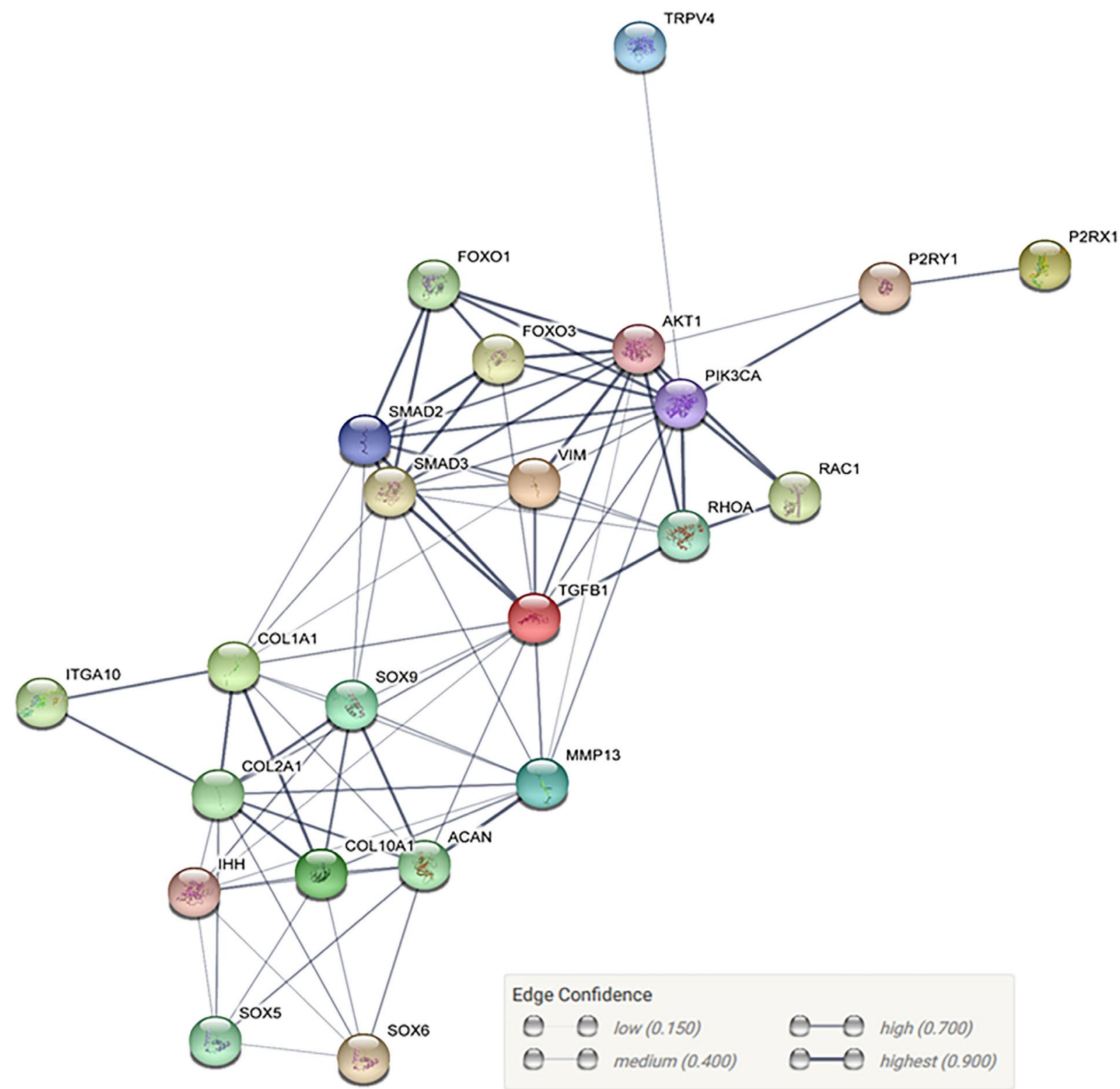

Fig. 5. STRING database analysis based on genes and proteins under the influence of hydrostatic pressure and chondrogenesis, showing the probability of protein interactions. 
remain open questions that need to be addressed in future investigations.

The optimal loading conditions for anabolism remain unclear due to differences in loading parameters (i.e. peak pressure, frequency) among studies. Furthermore, the timing and length of loading under pressure also differ. Meyer et al. (2011) demonstrated that pressure has a larger effect when applied continuously as compared to loading from day 21 onwards within a cellscaffold model. This potentially indicates that the embryonic and mesenchymal stages are the points of chondrogenesis under the greatest influence of pressure, corresponding to the theoretical models and early publications on hydrostatic pressure-induced chondrogenesis (Angele et al., 2003; Ogawa et al., 2009). However, there remains an open question regarding the timing of loading or length of preconditioning. Furthermore, expression of endogenous TGF- $\beta$ and other pro-chondrogenic factors by MSCs under hydrostatic pressure, with or without pre-stimulation, is incompletely studied. It may be hypothesised that the length of preconditioning could influence this latter phenomenon.

Based on theoretical models, hydrostatic pressure has been shown to stabilise the chondrocyte phenotype and, thus, prevent hypertrophy. However, publications have described both prevention and enhancement of hypertrophy gene expression (collagen X and MMP-13) under hydrostatic pressure. One method to prevent hypertrophy is physioxic culture. In vivo, cartilage resides under a low-oxygen condition between 2-5\% oxygen or physioxia (Brighton and Heppenstall, 1971; Lafont, 2010; LundOlesen, 1970) and recent investigations have shown that hypertrophy may be prevented under physioxia (Adesida et al., 2012; Anderson et al., 2016; Lee et al., 2013). Combining physioxia and pressure may be a solution for preventing hypertrophy during MSC chondrogenesis.

A variety of mechanisms for mechanotransduction under hydrostatic pressure have been explored, particularly those associated with purinergic and calcium signalling. However, the receptors and channels involved in transducing the signal need to be established. This could uncover previously unknown pathways involved in transduction of hydrostatic pressure in chondrogenic MSCs. To date, TRPV4, $\alpha_{10} \beta_{1}$ integrin and GPCRs are candidate receptors that may be activated under hydrostatic pressure (Fig. 3) (Bengtsson et al, 2005; Lee et al, 2013; O'Conor et al., 2014; Phan et al., 2009; Shah et al., 2014; Varas et al., 2007).

To develop an understanding of the interactions that could be under the influence of pressure, Szklarczyk et al. (2015) performed a STRING analysis based on the literature and hypothesising that membrane receptors and channels may be involved in hydrostatic pressure chondrogenesis (Fig. 4). The analysis shows the relationships among proteins based on experimental and theoretical results compiled and evaluated from various databases and predicts the probability of interactions among them. Fig. 4 shows the interactions based on experiments and curated databases, whilst also checking for evidence from text mining. The analysis indicates a major interaction among PI3K/FoxO, TGF- $\beta /$ SMAD and GTPases (RhoA and Rac1), whilst the associated chondrogenic genes are grouped together. Probability analysis of these interactions in the described pathways shows high correlations among the described downstream pathways and chondrogenic genes (Fig. 5). Purinergic signalling receptors, P2YR1 and P2XR2, demonstrate a strong interaction with respect to PI3K pathway, which is expected due to P2Y receptors interaction with GPCRs; although, studies performed under hydrostatic pressure have not directly examined this link. Furthermore, the STRING assessment also indicates no evidence for direct interactions between the PI3K pathway, chondrogenesis genes or upstream ion channels, e.g. TRPV4. Most interactions between pathways and chondrogenic genes involve TGF- $\beta$, as indicated by its centrality in both networks. This is not surprising since TGF- $\beta$ is a growth factor that stimulates chondrogenesis. However, the analysis shows that there are many targets described in the literature that require further investigation in the context of hydrostatic pressure.

In summary, hydrostatic pressure has a positive influence on MSC chondrogenesis, increasing both genes and matrix proteins. However, there remains conjecture on the timing at which it induces the most beneficial response and whether it prevents hypertrophy. The underlying mechanisms controlling the hydrostatic pressure response remain to be elucidated and may offer new targets for therapies if novel pathways that exerts its positive effects are found.

\section{Acknowledgements}

This work was supported by the DFG Research network (FOR2407/1) ExCarBon (SP7: Preconditioning of mesenchymal stem cells with mechanobiological load and hypoxia for joint regeneration in moderate OA).

\section{References}

Adesida AB, Mulet-Sierra A, Jomha NM (2012) Hypoxia mediated isolation and expansion enhances the chondrogenic capacity of bone marrow mesenchymal stromal cells. Stem Cell Res Ther 3: 9. DOI: $10.1186 /$ scrt100.

Ahamed J, Burg N, Yoshinaga K, Janczak CA, Rifkin DB, Coller BS (2008) In vitro and in vivo evidence for shear-induced activation of latent transforming growth factor-beta1. Blood 112: 36503660 . 
Akasaki Y, Hasegawa A, Saito M, Asahara H, Iwamoto Y, Lotz MK (2014) Dysregulated FOXO transcription factors in articular cartilage in aging and osteoarthritis. Osteoarthritis Cartilage 22: 162-170.

Albro MB, Cigan AD, Nims RJ, Yeroushalmi KJ, Oungoulian SR, Hung CT, Ateshian GA (2012) Shearing of synovial fluid activates latent TGF-beta. Osteoarthritis Cartilage 20: 1374-1382.

Anderson DE, Johnstone B (2017) Dynamic mechanical compression of chondrocytes for tissue engineering: a critical review. Front Bioeng Biotechnol 5: 76. DOI: 10.3389/fbioe.2017.00076.

Anderson DE, Markway BD, Bond D, McCarthy HE, Johnstone B (2016) Responses to altered oxygen tension are distinct between human stem cells of high and low chondrogenic capacity. Stem Cell Res Ther 7: 154. DOI: 10.1186/s13287-016-0419-8.

Angele P, Fritz J, Albrecht D, Koh J, Zellner J (2015) Defect type, localization and marker gene expression determines early adverse events of matrix-associated autologous chondrocyte implantation. Injury 46 Suppl 4: S2-9.

Angele P, Yoo JU, Smith C, Mansour J, Jepsen KJ, Nerlich M, Johnstone B (2003) Cyclic hydrostatic pressure enhances the chondrogenic phenotype of human mesenchymal progenitor cells differentiated in vitro. J Orthop Res 21: 451-457.

Bachrach NM, Mow VC, Guilak F (1998) Incompressibility of the solid matrix of articular cartilage under high hydrostatic pressures. J Biomech 31: $445-451$.

Bell A (2008) The pipe and the pinwheel: is pressure an effective stimulus for the $9+0$ primary cilium? Cell Biol Int 32: 462-468.

Bengtsson T, Aszodi A, Nicolae C, Hunziker EB, Lundgren-Akerlund E, Fassler R (2005) Loss of alpha10beta1 integrin expression leads to moderate dysfunction of growth plate chondrocytes. J Cell Sci 118: 929-936.

Bobick BE, Tuan RS, Chen FH (2010) The intermediate filament vimentin regulates chondrogenesis of adult human bone marrowderived multipotent progenitor cells. J Cell Biochem 109: 265-276.

Bodle JC, Loboa EG (2016) Concise review: primary cilia: control centers for stem cell lineage specification and potential targets for cell-based therapies. Stem Cells 34: 1445-1454.

Brighton CT, Heppenstall RB (1971) Oxygen tension in zones of the epiphyseal plate, the metaphysis and diaphysis. An in vitro and in vivo study in rats and rabbits. J Bone Joint Surg Am 53: 719-728.

Brittberg M, Lindahl A, Nilsson A, Ohlsson C, Isaksson O, Peterson L (1994) Treatment of deep cartilage defects in the knee with autologous chondrocyte transplantation. N Engl J Med 331: 889895.

Buckwalter JA, Mankin HJ, Grodzinsky AJ (2005) Articular cartilage and osteoarthritis. Instr Course Lect 54: 465-480.
Caplan AI (1991) Mesenchymal stem cells. J Orthop Res 9: 641-650.

Carroll SF, Buckley CT, Kelly DJ (2014) Cyclic hydrostatic pressure promotes a stable cartilage phenotype and enhances the functional development of cartilaginous grafts engineered using multipotent stromal cells isolated from bone marrow and infrapatellar fat pad. J Biomech 47: 2115-2121.

Carter DR, Wong M (2003) Modelling cartilage mechanobiology. Philos Trans R Soc Lond B Biol Sci 358: 1461-1471.

Clark AL, Votta BJ, Kumar S, Liedtke W, Guilak F (2010) Chondroprotective role of the osmotically sensitive ion channel transient receptor potential vanilloid 4: age- and sex-dependent progression of osteoarthritis in Trpv4-deficient mice. Arthritis Rheum 62: 2973-2983.

Cleary MA, van Osch GJ, Brama PA, Hellingman CA, Narcisi R (2015) FGF, TGFbeta and Wnt crosstalk: embryonic to in vitro cartilage development from mesenchymal stem cells. J Tissue Eng Regen Med 9: 332-342.

Correia C, Pereira AL, Duarte AR, Frias AM, Pedro AJ, Oliveira JT, Sousa RA, Reis RL (2012) Dynamic culturing of cartilage tissue: the significance of hydrostatic pressure. Tissue Eng Part A 18: 1979-1991.

Daniels K, Solursh M (1991) Modulation of chondrogenesis by the cytoskeleton and extracellular matrix. J Cell Sci 100: 249-254.

Daniels KJ, Sandra A (1990) Cytoskeletal organization and synthesis in substrate-independent and -dependent myogenesis in chick embryos. Anat Rec 227: 254-263.

Docheva D, Popov C, Alberton P, Aszodi A (2014) Integrin signaling in skeletal development and function. Birth Defects Res C Embryo Today 102: 13-36.

Elder BD, Athanasiou KA (2009) Hydrostatic pressure in articular cartilage tissue engineering: from chondrocytes to tissue regeneration. Tissue Eng Part B Rev 15: 43-53.

Elder SH, Shim JW, Borazjani A, Robertson HM, Smith KE, Warnock JN (2008) Influence of hydrostatic and distortional stress on chondroinduction. Biorheology 45: 479-486.

Erickson IE, Huang AH, Chung C, Li RT, Burdick JA, Mauck RL (2009) Differential maturation and structure-function relationships in mesenchymal stem cell- and chondrocyte-seeded hydrogels. Tissue Eng Part A 15: 1041-1052.

Finger AR, Sargent CY, Dulaney KO, Bernacki SH, Loboa EG (2007) Differential effects on messenger ribonucleic acid expression by bone marrow-derived human mesenchymal stem cells seeded in agarose constructs due to ramped and steady applications of cyclic hydrostatic pressure. Tissue Eng 13: 1151-1158.

Gardner OF, Fahy N, Alini M, Stoddart MJ (2016b) Joint mimicking mechanical load activates TGFbeta1 in fibrin-poly(ester-urethane) scaffolds seeded with mesenchymal stem cells. J Tissue Eng Regen Med 11: 2663-2666. 
Gimble J, Guilak F (2003) Adipose-derived adult stem cells: isolation, characterization, and differentiation potential. Cytotherapy 5: 362-369.

Giorgi M, Carriero A, Shefelbine SJ, Nowlan NC (2014) Mechanobiological simulations of prenatal joint morphogenesis. J Biomech 47: 989-995.

Goldring MB (2000) Osteoarthritis and cartilage: the role of cytokines. Curr Rheumatol Rep 2: 459-465.

Goldring MB, Otero M, Plumb DA, Dragomir C, Favero M, El Hachem K, Hashimoto K, Roach HI, Olivotto E, Borzi RM, Marcu KB (2011) Roles of inflammatory and anabolic cytokines in cartilage metabolism: signals and multiple effectors converge upon MMP-13 regulation in osteoarthritis. Eur Cell Mater 21: 202-220.

Hall AC (1999) Differential effects of hydrostatic pressure on cation transport pathways of isolated articular chondrocytes. J Cell Physiol 178: 197-204.

Heo SJ, Cosgrove BD, Dai EN, Mauck RL (2018) Mechano-adaptation of the stem cell nucleus. Nucleus 9: 9-19.

Huang AH, Farrell MJ, Mauck RL (2010a) Mechanics and mechanobiology of mesenchymal stem cell-based engineered cartilage. J Biomech 43: 128-136.

Huang AH, Stein A, Mauck RL (2010b) Evaluation of the complex transcriptional topography of mesenchymal stem cell chondrogenesis for cartilage tissue engineering. Tissue Eng Part A 16: 2699-2708.

Jablonski CL, Ferguson S, Pozzi A, Clark AL (2014) Integrin alpha1beta1 participates in chondrocyte transduction of osmotic stress. Biochem Biophys Res Commun 445: 184-190.

Johnstone B, Hering TM, Caplan AI, Goldberg VM, Yoo JU (1998) In vitro chondrogenesis of bone marrow-derived mesenchymal progenitor cells. Exp Cell Res 238: 265-272.

Karkhaneh A, Naghizadeh Z, Shokrgozar MA, Bonakdar S, Solouk A, Haghighipour N (2014) Effects of hydrostatic pressure on biosynthetic activity during chondrogenic differentiation of MSCs in hybrid scaffolds. Int J Artif Organs 37: 142-148.

Knight MM, McGlashan SR, Garcia M, Jensen CG, Poole CA (2009) Articular chondrocytes express connexin 43 hemichannels and P2 receptors - a putative mechanoreceptor complex involving the primary cilium? J Anat 214: 275-283.

Krupkova O, Zvick J, Wuertz-Kozak K (2017) The role of transient receptor potential channels in joint diseases. Eur Cell Mater 34: 180-201.

Lafont JE (2010) Lack of oxygen in articular cartilage: consequences for chondrocyte biology. Int J Exp Pathol 91: 99-106.

Lamande SR, Yuan Y, Gresshoff IL, Rowley L, Belluoccio D, Kaluarachchi K, Little CB, Botzenhart E, Zerres K, Amor DJ, Cole WG, Savarirayan R, McIntyre P, Bateman JF (2011) Mutations in TRPV4 cause an inherited arthropathy of hands and feet. Nat Genet 43: 1142-1146.

LaPointe VL, Verpoorte A, Stevens MM (2013) The changing integrin expression and a role for integrin beta8 in the chondrogenic differentiation of mesenchymal stem cells. PLoS One 8: e82035. DOI: 10.1371/journal.pone.0082035.

Lee HH, Chang CC, Shieh MJ, Wang JP, Chen YT, Young TH, Hung SC (2013) Hypoxia enhances chondrogenesis and prevents terminal differentiation through PI3K/Akt/FoxO dependent anti-apoptotic effect. Sci Rep 3: 2683. DOI: 10.1038/srep02683.

Lefebvre V, Behringer RR, de Crombrugghe B (2001) L-Sox5, Sox6 and Sox9 control essential steps of the chondrocyte differentiation pathway. Osteoarthritis Cartilage 9 Suppl A: S69-75.

Lefebvre V, Huang W, Harley VR, Goodfellow PN, de Crombrugghe B (1997) SOX9 is a potent activator of the chondrocyte-specific enhancer of the pro alpha1(II) collagen gene. Mol Cell Biol 17: 2336-2346.

Lewis R, Barrett-Jolley R (2015) Changes in membrane receptors and ion channels as potential biomarkers for osteoarthritis. Front Physiol 6: 357. DOI: 10.3389/fphys.2015.00357.

Li J, Wang J, Zou Y, Zhang Y, Long D, Lei L, Tan L, Ye R, Wang X, Zhao Z (2012) The influence of delayed compressive stress on TGF-beta1-induced chondrogenic differentiation of rat BMSCs through Smad-dependent and Smad-independent pathways. Biomaterials 33: 8395-8405.

Li J, Zhao Z, Yang J, Liu J, Wang J, Li X, Liu Y (2009) p38 MAPK mediated in compressive stressinduced chondrogenesis of rat bone marrow MSCs in 3D alginate scaffolds. J Cell Physiol 221: 609-617.

Li Y, Zhou J, Yang X, Jiang Y, Gui J (2016) Intermittent hydrostatic pressure maintains and enhances the chondrogenic differentiation of cartilage progenitor cells cultivated in alginate beads. Dev Growth Differ 58: 180-193.

Li Z, Kupcsik L, Yao SJ, Alini M, Stoddart MJ (2010) Mechanical load modulates chondrogenesis of human mesenchymal stem cells through the TGF-beta pathway. J Cell Mol Med 14: 1338-1346.

Liu Y, Buckley CT, Almeida HV, Mulhall KJ, Kelly DJ (2014) Infrapatellar fat pad-derived stem cells maintain their chondrogenic capacity in disease and can be used to engineer cartilaginous grafts of clinically relevant dimensions. Tissue Eng Part A 20: 3050-3062.

Loeser RF (2014) Integrins and chondrocytematrix interactions in articular cartilage. Matrix Biol 39: 11-16.

Lund-Olesen K (1970) Oxygen tension in synovial fluids. Arthritis Rheum 13: 769-776.

Lundgren-Akerlund E, Aszodi A (2014) Integrin alpha10beta1: a collagen receptor critical in skeletal development. Adv Exp Med Biol 819: 61-71.

Luo ZJ, Seedhom BB (2007) Light and lowfrequency pulsatile hydrostatic pressure enhances extracellular matrix formation by bone marrow mesenchymal cells: an in-vitro study with special reference to cartilage repair. Proc Inst Mech Eng H 221: 499-507.

Luyten FP, Denti M, Filardo G, Kon E, Engebretsen L (2012) Definition and classification of early 
osteoarthritis of the knee. Knee Surg Sports Traumatol Arthrosc 20: 401-406.

Madry H, Kon E, Condello V, Peretti GM, Steinwachs M, Seil R, Berruto M, Engebretsen L, Filardo G, Angele P (2016) Early osteoarthritis of the knee. Knee Surg Sports Traumatol Arthrosc 24: 17531762.

Madry H, Luyten FP, Facchini A (2012) Biological aspects of early osteoarthritis. Knee Surg Sports Traumatol Arthrosc 20: 407-422.

Maroudas A, Bannon C (1981) Measurement of swelling pressure in cartilage and comparison with the osmotic pressure of constituent proteoglycans. Biorheology 18: 619-632.

Martins RP, Finan JD, Guilak F, Lee DA (2012) Mechanical regulation of nuclear structure and function. Annu Rev Biomed Eng 14: 431-455.

Matsuzaki T, Alvarez-Garcia O, Mokuda S, Nagira K, Olmer M, Gamini R, Miyata K, Akasaki Y, Su AI, Asahara H, Lotz MK (2018) FoxO transcription factors modulate autophagy and proteoglycan 4 in cartilage homeostasis and osteoarthritis. Sci Transl Med 10. pii: eaan0746. DOI: 10.1126/scitranslmed.aan0746.

Maxson S, Burg KL (2012) Synergistic effects of conditioned media and hydrostatic pressure on the differentiation of mesenchymal stem cells. Cell Mol Bioeng 5: 414-426.

McGlashan SR, Jensen CG, Poole CA (2006) Localization of extracellular matrix receptors on the chondrocyte primary cilium. J Histochem Cytochem 54: 1005-1014.

McNulty AL, Rothfusz NE, Leddy HA, Guilak F (2013) Synovial fluid concentrations and relative potency of interleukin-1 alpha and beta in cartilage and meniscus degradation. J Orthop Res 31: 10391045.

Meyer EG, Buckley CT, Steward AJ, Kelly DJ (2011) The effect of cyclic hydrostatic pressure on the functional development of cartilaginous tissues engineered using bone marrow derived mesenchymal stem cells. J Mech Behav Biomed Mater 4: 1257-1265.

Millward-Sadler SJ, Wright MO, Flatman PW, Salter DM(2004) ATP in themechanotransduction pathway of normal human chondrocytes. Biorheology 41: 567-575.

Miyanishi K, Trindade MC, Lindsey DP, Beaupre GS, Carter DR, Goodman SB, Schurman DJ, Smith RL (2006) Dose- and time-dependent effects of cyclic hydrostatic pressure on transforming growth factorbeta3-induced chondrogenesis by adult human mesenchymal stem cells in vitro. Tissue Eng 12: 22532262.

Mizuno S (2005) A novel method for assessing effects of hydrostatic fluid pressure on intracellular calcium: a study with bovine articular chondrocytes. Am J Physiol Cell Physiol 288: C329-337.

Mobasheri A, Carter SD, Martin-Vasallo P, Shakibaei M (2002) Integrins and stretch activated ion channels; putative components of functional cell surface mechanoreceptors in articular chondrocytes. Cell Biol Int 26: 1-18.
Mow VC, Holmes MH, Lai WM (1984) Fluid transport and mechanical properties of articular cartilage: a review. J Biomech 17: 377-394.

Muramatsu S, Wakabayashi M, Ohno T, Amano K, Ooishi R, Sugahara T, Shiojiri S, Tashiro K, Suzuki Y, Nishimura R, Kuhara S, Sugano S, Yoneda T, Matsuda A (2007) Functional gene screening system identified TRPV4 as a regulator of chondrogenic differentiation. J Biol Chem 282: 32158-32167.

Niemeyer P, Schweigler K, Grotejohann B, Maurer J, Angele P, Aurich M, Becher C, Fay J, Feil R, Fickert S, Fritz J, Hoburg A, Kreuz P, Kolombe T, Laskowski J, Lutzner J, Marlovits S, Muller PE, Niethammer T, Pietschmann M, Ruhnau K, Spahn G, Tischer T, Zinser W, Albrecht D (2015) [The German Cartilage Registry (KnorpelRegister DGOU) for evaluation of surgical treatment for cartilage defects: experience after six months including first demographic data] [Article in German]. Z Orthop Unfall 153: 67-74.

O'Conor CJ, Case N, Guilak F (2013) Mechanical regulation of chondrogenesis. Stem Cell Res Ther 4: 61. DOI: $10.1186 /$ scrt211.

O'Conor CJ, Leddy HA, Benefield HC, Liedtke WB, Guilak F (2014) TRPV4-mediated mechanotransduction regulates the metabolic response of chondrocytes to dynamic loading. Proc Natl Acad Sci U S A 111: 1316-1321.

O'Conor CJ, Ramalingam S, Zelenski NA, Benefield HC, Rigo I, Little D, Wu CL, Chen D, Liedtke W, McNulty AL, Guilak F (2016) Cartilagespecific knockout of the mechanosensory ion channel trpv4 decreases age-related osteoarthritis. Sci Rep 6: 29053. DOI: 10.1038/srep29053.

Ogawa R, Mizuno S, Murphy GF, Orgill DP (2009) The effect of hydrostatic pressure on threedimensional chondroinduction of human adiposederived stem cells. Tissue Eng Part A 15: 2937-2945.

Ogawa R, Orgill DP, Murphy GF, Mizuno S (2015) Hydrostatic pressure-driven three-dimensional cartilage induction using human adipose-derived stem cells and collagen gels. Tissue Eng Part A 21: 257-266.

Pelttari K, Winter A, Steck E, Goetzke K, Hennig T, Ochs BG, Aigner T, Richter W (2006) Premature induction of hypertrophy during in vitro chondrogenesis of human mesenchymal stem cells correlates with calcification and vascular invasion after ectopic transplantation in SCID mice. Arthritis Rheum 54: 3254-3266.

Phan MN, Leddy HA, Votta BJ, Kumar S, Levy DS, Lipshutz DB, Lee SH, Liedtke W, Guilak F (2009) Functional characterization of TRPV4 as an osmotically sensitive ion channel in porcine articular chondrocytes. Arthritis Rheum 60: 3028-3037.

Pittenger MF, Mackay AM, Beck SC, Jaiswal RK, Douglas R, Mosca JD, Moorman MA, Simonetti DW, Craig S, Marshak DR (1999) Multilineage potential of adult human mesenchymal stem cells. Science 284: 143-147.

Puetzer J, Williams J, Gillies A, Bernacki S, Loboa EG (2013) The effects of cyclic hydrostatic pressure 
on chondrogenesis and viability of human adiposeand bone marrow-derived mesenchymal stem cells in three-dimensional agarose constructs. Tissue Eng Part A 19: 299-306.

Richette P, Corvol M, Bardin T (2003) Estrogens, cartilage, and osteoarthritis. Joint Bone Spine 70: 257262.

Safshekan F, Tafazzoli-Shadpour M, Shokrgozar MA, Haghighipour N, Mahdian R, Hemmati A (2012) Intermittent hydrostatic pressure enhances growth factor-induced chondroinduction of human adiposederived mesenchymal stem cells. Artif Organs 36: 1065-1071.

Saha A, Rolfe R, Carroll S, Kelly DJ, Murphy P (2017) Chondrogenesis of embryonic limb bud cells in micromass culture progresses rapidly to hypertrophy and is modulated by hydrostatic pressure. Cell Tissue Res 368: 47-59.

Sahyoun NR, Brett KM, Hochberg MC, Pamuk ER (1999) Estrogen replacement therapy and incidence of self-reported physician-diagnosed arthritis. Prev Med 28: 458-464.

Sakaguchi Y, Sekiya I, Yagishita K, Muneta T (2005) Comparison of human stem cells derived from various mesenchymal tissues: superiority of synovium as a cell source. Arthritis Rheum 52: 2521-2529.

Sakao K, Takahashi KA, Arai Y, Inoue A, Tonomura H, Saito M, Yamamoto T, Kanamura N, Imanishi J, Mazda O, Kubo T (2008) Induction of chondrogenic phenotype in synovium-derived progenitor cells by intermittent hydrostatic pressure. Osteoarthritis Cartilage 16: 805-814.

Salinas EY, Hu JC, Athanasiou K (2018) A guide for using mechanical stimulation to enhance tissueengineered articular cartilage properties. Tissue Eng Part B Rev 24: 345-358.

Schatti O, Grad S, Goldhahn J, Salzmann G, Li Z, Alini M, Stoddart MJ (2011) A combination of shear and dynamic compression leads to mechanically induced chondrogenesis of human mesenchymal stem cells. Eur Cell Mater 22: 214-225.

Shah N, Morsi Y, Manasseh R (2014) From mechanical stimulation to biological pathways in the regulation of stem cell fate. Cell Biochem Funct 32: 309-325.

Soltz MA, Ateshian GA (1998) Experimental verification and theoretical prediction of cartilage interstitial fluid pressurization at an impermeable contact interface in confined compression. J Biomech 31: 927-934.

Soltz MA, Ateshian GA (2000) Interstitial fluid pressurization during confined compression cyclical loading of articular cartilage. Ann Biomed Eng 28: 150-159.

Sophia Fox AJ, Bedi A, Rodeo SA (2009) The basic science of articular cartilage: structure, composition, and function. Sports Health 1: 461-468.

Steward AJ, Kelly DJ, Wagner DR (2014) The role of calcium signalling in the chondrogenic response of mesenchymal stem cells to hydrostatic pressure. Eur Cell Mater 28: 358-371.
Steward AJ, Kelly DJ, Wagner DR (2016) Purinergic signaling regulates the transforming growth factor-beta3-induced chondrogenic response of mesenchymal stem cells to hydrostatic pressure. Tissue Eng Part A 22: 831-839.

Steward AJ, Thorpe SD, Vinardell T, Buckley CT, Wagner DR, Kelly DJ (2012) Cell-matrix interactions regulate mesenchymal stem cell response to hydrostatic pressure. Acta Biomater 8: 2153-2159.

Steward AJ, Wagner DR, Kelly DJ (2013) The pericellular environment regulates cytoskeletal development and the differentiation of mesenchymal stem cells and determines their response to hydrostatic pressure. Eur Cell Mater 25: 167-178.

Szklarczyk D, Franceschini A, Wyder S, Forslund K, Heller D, Huerta-Cepas J, Simonovic M, Roth A, Santos A, Tsafou KP, Kuhn M, Bork P, Jensen LJ, von Mering C (2015) STRING v10: protein-protein interaction networks, integrated over the tree of life. Nucleic Acids Res 43: D447-452.

Thorpe SD, Buckley CT, Vinardell T, O’Brien FJ, Campbell VA, Kelly DJ (2010) The response of bone marrow-derived mesenchymal stem cells to dynamic compression following TGF-beta3 induced chondrogenic differentiation. Ann Biomed Eng 38: 2896-2909.

Urban JP (1994) The chondrocyte: a cell under pressure. Br J Rheumatol 33: 901-908.

Varas L, Ohlsson LB, Honeth G, Olsson A, Bengtsson T, Wiberg C, Bockermann R, Jarnum S, Richter J, Pennington D, Johnstone B, LundgrenAkerlund E, Kjellman C (2007) Alpha10 integrin expression is up-regulated on fibroblast growth factor-2-treated mesenchymal stem cells with improved chondrogenic differentiation potential. Stem Cells Dev 16: 965-978.

Vinardell T, Rolfe RA, Buckley CT, Meyer EG, Ahearne M, Murphy P, Kelly DJ (2012) Hydrostatic pressure acts to stabilise a chondrogenic phenotype in porcine joint tissue derived stem cells. Eur Cell Mater 23: 121-134.

Wagner DR, Lindsey DP, Li KW, Tummala P, Chandran SE, Smith RL, Longaker MT, Carter DR, Beaupre GS (2008) Hydrostatic pressure enhances chondrogenic differentiation of human bone marrow stromal cells in osteochondrogenic medium. Ann Biomed Eng 36: 813-820.

Wann AK, Zuo N, Haycraft CJ, Jensen CG, Poole CA, McGlashan SR, Knight MM (2012) Primary cilia mediate mechanotransduction through control of ATP-induced Ca2+ signaling in compressed chondrocytes. FASEB J 26: 1663-1671.

Wluka AE, Davis SR, Bailey M, Stuckey SL, Cicuttini FM (2001) Users of oestrogen replacement therapy have more knee cartilage than non-users. Ann Rheum Dis 60: 332-336.

Woods A, Beier F (2006) RhoA/ROCK signaling regulates chondrogenesis in a context-dependent manner. J Biol Chem 281: 13134-13140.

Woods A, Wang G, Beier F (2005) RhoA/ROCK signaling regulates Sox 9 expression and actin 
organization during chondrogenesis. J Biol Chem 280: 11626-11634.

Woods A, Wang G, Dupuis H, Shao Z, Beier F (2007) Rac1 signaling stimulates $\mathrm{N}$-cadherin expression, mesenchymal condensation, and chondrogenesis. J Biol Chem 282: 23500-23508.

Ye R, Hao J, Song J, Zhao Z, Fang S, Wang $Y$, Li J (2014) Microenvironment is involved in cellular response to hydrostatic pressures during chondrogenesis of mesenchymal stem cells. J Cell Biochem 115: 1089-1096.

Yoo JU, Barthel TS, Nishimura K, Solchaga L, Caplan AI, Goldberg VM, Johnstone B (1998) The chondrogenic potential of human bone-marrowderived mesenchymal progenitor cells. J Bone Joint Surg Am 80: 1745-1757.

Zhao Y, Yi FZ, Zhao YH, Chen YJ, Ma H, Zhang M (2016) The distinct effects of estrogen and hydrostatic pressure on mesenchymal stem cells differentiation: involvement of estrogen receptor signaling. Ann Biomed Eng 44: 2971-2983.

Zhao YH, Lv X, Liu YL, Zhao Y, Li Q, Chen YJ, Zhang M (2015) Hydrostatic pressure promotes the proliferation and osteogenic/chondrogenic differentiation of mesenchymal stem cells: the roles of RhoA and Rac1. Stem Cell Res 14: 283-296.

\section{Discussion with Reviewers}

Farshid Guilak: MSCs respond to various mechanical stimuli. Can the authors comment on their relative contribution?

Authors: Researchers have begun to examine the relative contribution of different physical stimuli (compressive, tensile, shear and hydrostatic pressure) to MSC chondrogenesis using both experimental and computational models. Schatti et al. (2011) showed that uniaxial compression and shear alone is insufficient to induce MSC chondrogenesis but that combined compression and shear are required for chondrogenic induction. Finite element analysis shows that compressive deformation of an MSC-seeded fibrinpolyurethane scaffold resulting from combined cyclic compression and shear loading is the principal stimulus that induces MSC chondrogenesis under load (Zahedmanesh et al., 2014, additional reference). However, as noted by the authors and in relation to the present review, the high scaffold porosity results in negligible involvement of hydrostatic pressure due to water being released from the scaffold upon compression. However, MSCs, seeded in scaffolds with a lower porosity (e.g. agarose) that mimic native articular cartilage, demonstrate chondrogenic induction under uniaxial compressive loading due to the presence of both compressive and hydrostatic pressure. The latter stimulus is present due to a reduction in fluid loss within the system. In contrast to the previously described model, chondrogenesis occurs in areas of maximum hydrostatic pressure
(Kisiday et al., 2009, additional reference). Thus, further in vitro and computational modelling studies are required to delineate the relative contribution of these different stimuli to MSC chondrogenesis, especially in multiaxial loading systems.

Daniel Kelly: In vivo, implanted cells will be subjected to high levels of hydrostatic pressure. Based on the review of the literature, have the authors found any evidence to suggest that MSCs require pre-culture to respond positively to hydrostatic pressure (in terms of either increases in matrix deposition or suppression of hypertrophy) or should MSCs be able to respond positively to the hydrostatic pressure they experience in vivo without pre-culture?

Authors: To the authors' knowledge, there is no understanding about whether MSCs react positively to in vivo hydrostatic pressure with or without preculture. No published studies describe implantation of hydrostatic-pressure-stimulated chondrogenic MSCs into animal models. This is clearly an area in need of testing.

Daniel Kelly: Is there any evidence suggesting that the beneficial effects of hydrostatic pressure on chondrogenesis can be mimicked by specific drugs? Authors: The authors are unaware of specific drugs that mimic the beneficial effects of hydrostatic pressure on MSC chondrogenesis. However, it is possible that the secreted factors (including paracrine factors, exosomes and microvesicles) released from MSCs during pressure stimulation may be exploited in this manner. Recent publications have addressed the importance of the secreted factors released during mechanical stimulation in MSC chondrogenesis, particularly in dynamic loading systems (compression and shear) conditions (Fahy et al., 2018; Gardner et al., 2016a; Phelps et al., 2018; Vonk et al., 2018, additional references). Further investigations into the MSC chondrogenic secretome under hydrostatic pressure could potentially lead to the development of drugs that utilise these factors. Furthermore, drugs that target specific pathways that are known to be involved in the pressure-induced anabolic response would also be exploitable for drug development.

\section{Additional References}

Fahy N, Alini M, Stoddart MJ (2018) Mechanical stimulation of mesenchymal stem cells: implications for cartilage tissue engineering. J Orthop Res 36: 5263.

Gardner OF, Fahy N, Alini M, Stoddart MJ (2016a) Differences in human mesenchymal stem cell secretomes during chondrogenic induction. Eur Cell Mater 31: 221-235.

Kisiday JD, Frisbie DD, McIlwraith CW, Grodzinsky AJ (2009) Dynamic compression 
stimulates proteoglycan synthesis by mesenchymal stem cells in the absence of chondrogenic cytokines. Tissue Eng Part A 15: 2817-2824.

Vonk LA, van Dooremalen SFJ, Liv N, Klumperman J, Coffer PJ, Saris DBF, Lorenowicz MJ (2018) Mesenchymal stromal/stem cell-derived extracellular vesicles promote human cartilage regeneration in vitro. Theranostics 8: 906-920.

Zahedmanesh H, Stoddart M, Lezuo P, Forkmann C, Wimmmer MA, Alini M, Van Oosterwyck
H (2014) Deciphering mechanical regulation of chondrogenesis in fibrin-polyurethane composite scaffolds enriched with human mesenchymal stem cells: a dual computational and experimental approach. Tissue Eng Part A 20: 1197-1212.

Editor's note: The Scientific Editor responsible for this paper was Martin Stoddart. 